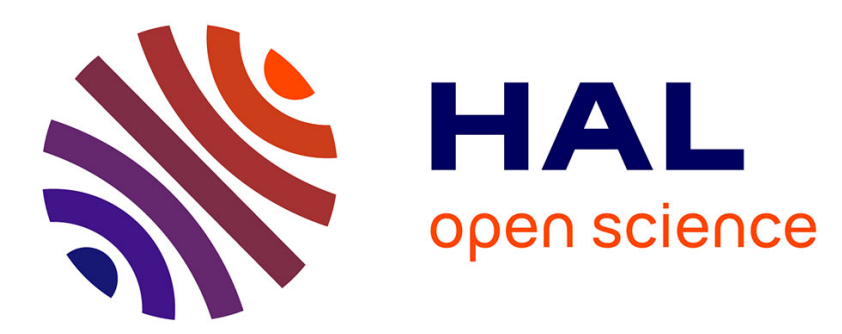

\title{
Awesome forces and warning signs: Charting the semantic history of tabu words in Vanuatu
}

Alexandre François

\section{To cite this version:}

Alexandre François. Awesome forces and warning signs: Charting the semantic history of tabu words in Vanuatu. Oceanic Linguistics, 2022, 61 (1), pp.212-255. 10.1353/ol.2022.0017 . halshs-03092520

\section{HAL Id: halshs-03092520 \\ https://shs.hal.science/halshs-03092520}

Submitted on 23 Dec 2021

HAL is a multi-disciplinary open access archive for the deposit and dissemination of scientific research documents, whether they are published or not. The documents may come from teaching and research institutions in France or abroad, or from public or private research centers.
L'archive ouverte pluridisciplinaire HAL, est destinée au dépôt et à la diffusion de documents scientifiques de niveau recherche, publiés ou non, émanant des établissements d'enseignement et de recherche français ou étrangers, des laboratoires publics ou privés. 


\title{
Awesome forces and warning signs Charting the semantic history of *tabu words in Vanuatu
}

\author{
Alexandre François \\ LATTICE, CNRS-ENS-SORBONNE NOUVELLE \\ AUSTRALIAN NATIONAL UNIVERSITY
}

The Proto-Oceanic etymon *tabu has hardly been studied outside Polynesian, yet it is attested in other Oceanic languages - albeit with different meanings. This study describes the polysemies observed for modern reflexes of *tabu, with an initial focus on Vanuatu. Sometimes, *tabu words simply refer to the mundane warning signs put up in various locations to fend off unwelcome visitors. But reflexes of *tabu are more often linked with supernatural powers, good or evil, and with the sense of awe and fear they induce upon us. The root may evoke the numinous power of high-ranked dignitaries; or the world of ancestral spirits and ghosts, and the forces of death. The diverse array of meanings attached to *tabu words is best synthesized in the form of a semantic map. This visual tool helps picture the internal organization of the root's polysemy, and can be used as a background as we compare modern languages with each other. By applying principles of the Comparative method, we can reconstruct the meaning of *tabu at the level of ProtoOceanic: 'forbidden, off limits; sacred, due to a sentiment of awe before spiritual forces'. Finally, semantic maps reveal their full potential as we take a dynamic perspective, and retrace the evolution of *tabu from its original meanings to the various polysemies it has acquired in modern languages.

Keywords: religion - sacred - taboo - spirit - etymology - semantic maps lexical reconstruction - Proto-Oceanic - Vanuatu - cultural anthropology 


\section{THE PROBLEM: WHAT DID *TABU MEAN IN POC? ${ }^{1}$}

1.1 A RELIGIOUS TERM? The English word taboo was borrowed in the late $18^{\text {th }}$ century by Captain Cook from Tongan tapu. Cook's earliest account, dated from 1777, explained the term as essentially meaning 'forbidden':

"They were all taboo, as they said; which word has a very comprehensive meaning; but, in general, signifies that a thing is forbidden."

(June 1777, in Cook \& King 1784: 286; my emphasis)

"When any thing is forbidden to be eat, or made use of, they say, that it is taboo." (July 1777, in Cook \& King 1784: 410)

As Cook and his men pursued their travels and became acquainted with the meanings of tapu in different Polynesian languages, it soon was clear that the word did not refer to just any prohibition, that would apply to mundane matters. Instead, tapu was usually associated with a sense of sacredness, and with restrictions that the explorers would describe as "religious". Here is the account written by Captain King about the Sandwich Islands (Hawai'i):

"This sort of religious interdiction they call taboo; a word we heard often repeated during our stay amongst these islanders, and found to be of very powerful and extensive operation. On our inquiring into the reasons of the interdiction of all intercourse between us and the natives $(. .$.$) we were told$ that the bay was tabooed. (...)

They apply the word taboo indifferently both to persons and things. (...) This word is also used to express anything sacred, or eminent, or devoted." (Cook \& King 1793: 163)

A few decades later, Ellis (1831:385) would also describe "tabu" in religious terms: ${ }^{2}$

"In most of the Polynesian dialects, the usual meaning of the word tabu is sacred. It (...) expresses a connexion with the gods, or a separation from ordinary purposes, and exclusive appropriation to persons or things considered sacred. Those chiefs who trace their genealogy to the gods are called arii tabu, chiefs sacred, from their supposed connexion with the gods (...). This appears to be the legitimate meaning of the word tabu."

1. This work is part of the program Investissements d'Avenir overseen by the French Agence Nationale de la Recherche, ANR-10-LABX-0083 (LabEx EFL), section Typology and dynamics of linguistic systems. I wish to thank the organizers and participants of the workshop Diffusion \& change in lexical semantics: restriction, avoidance and 'tabu' (Canberra, July 2017) for their feedback; as well as Patrick McConvell, Andrew Pawley, and two anonymous reviewers, for their comments on earlier versions of this work. This paper is dedicated to the memory of Professor John Lynch.

2 Even though Polynesian forms all have a voiceless /p/ (tapu), the form was misheard and transcribed with a $b$ by early English authors, yielding such forms as taboo or tabu. It is an unrelated coincidence that the word reconstructs in Proto-Oceanic as a form *tabu [see §2.3] for what was phonetically [tam $\mathrm{bu}$ ]. In this paper, the starred form *tabu will always refer to the POc etymon. 
In subsequent literature, from Marett (1914) or Williamson (1937) to Keesing (1992) and beyond, the concept of tapu in Polynesian languages was often assigned to the realm of religion - suggesting that tapu meant more than just 'forbidden'.

Such observations are also reflected in some dictionaries of Polynesian languages. While the term occasionally receives a minimal gloss 'forbidden, prohibited', more elaborate definitions often add the notion of sacredness. Here is how, for example, Williams (1957 [1917]) defined tapu in his Dictionary of Māori:

"1. adj. Under religious or superstitious restriction; a condition affecting persons, places, and things, and arising from innumerable causes. Anyone violating tapu (...) was certain to be overtaken by calamity. As a rule, elaborate ceremonies were necessary to remove tapu and make anything noa. 2. Beyond one's power, inaccessible. 3. Sacred. 4. n. Ceremonial restriction."

One way to acknowledge the religious aspects of Polynesian tapu is to gloss it not just 'forbidden', but 'unapproachable, off limits, due to a sacred character or to a religious restriction' (cf. Keesing 1992).

While a great body of literature has been dedicated to tapu in Polynesian languages (see references above, and also Sachdev 1989; Fletcher 2007; Gilmore et al. 2013), few authors acknowledge that this root is also attested in Oceanic languages outside Polynesian. Indeed, the etymon reconstructs to Proto-Oceanic (POc) as *tabu [ta ${ }^{\mathrm{m}} \mathrm{bu}$ ] (Blust \& Trussel 2021); it has even been proposed at the level of PCEMP (Proto Central Eastern Malayo-Polynesian), as a form *tambu (ibid.).

Crucially, the gloss assigned by Blust \& Trussel (2021) to *tabu is minimal: 'forbidden, taboo'. This might be interpreted literally, as an indication that the only reconstructable meaning for that etymon is indeed the notion of prohibition - perhaps in the general, mundane sense. If so, a possibility would be that the religious meanings ('sacred, holy; under a ritual restriction...') were developed by Polynesian languages separately from the rest of the family. In comparison with other Oceanic cultures, the Polynesians are known for having innovated various social practices - notably, the existence of hereditary chiefs, endowed with religious sanctity - so it would not be implausible to propose that the spiritual connotations of tapu emerged only in that branch of the Oceanic family. In fact, Keesing (1992:237) seems to hint at such a possibility:

"[T]abu/tapu is found not only in Polynesian languages, but in many other Oceanic Austronesian languages, in Island Melanesia. Because the concept there usually occurs without an association with hereditary chiefs and their sanctity and political power, the Melanesian usages illuminate the Polynesian ones." 
While the latter sentence does sound promising, Keesing's text does not follow up on that proposal: like other authors, he restricts his discussion to Polynesian languages, saying little about Melanesian uses of the root *tabu.

The present paper intends to address this gap in our knowledge by exploring the Oceanic root *tabu outside Polynesia. I will focus on one specific region of Island Melanesia, namely Vanuatu. ${ }^{3}$ When useful, I will complement my observations with Oceanic languages from other areas.

1.2 OUTLINE OF THIS STUDY. What can we know about the semantics of *tabu in the Oceanic languages that have preserved that etymon, in Vanuatu and elsewhere? Do these languages also endow this word with religious meanings, and if so, of what nature? What methods can help us reconstruct the polysemy of *tabu all the way to Proto-Oceanic? What sorts of semantic innovations have taken place among the reflexes of that root?

Map 1 shows the location of the Vanuatu languages cited in this study. Within Oceanic, they all belong to the Southern Oceanic linkage - more precisely to the sublinkage known as North-Central Vanuatu (Clark 2009). The Appendix lists these languages, together with the word forms that reflect *tabu, and my data sources.

Within Vanuatu, my primary focus will be the Torres and Banks Islands, in the north. Indeed, this is where I have collected firsthand knowledge, both linguistic and ethnographic. My data, gathered during several field trips between 1997 and 2011, include a literary corpus of 389 oral narratives recorded in 22 languages (François 2021a). (In the present study, whenever the audio source of an example is accessible online, a footnote will provide a link to the text.) In addition to these recordings, some data were acquired through conversations during language immersion and participant observation, as I learned and observed the languages in their social context.

The second reason for focusing on the Torres and Banks Islands is that this turns out to be the area of Vanuatu where reflexes of the root*tabu show the richest array of meanings.

I will start this study with a preliminary discussion (Section 2) meant to circumscribe the exact scope of our research. While various forms of linguistic "taboos" exist in Vanuatu, they fall outside of our scope, as they are never expressed through a reflex of the root *tabu. If we set aside loanwords, what this paper calls "*tabu words" - namely, modern lexemes going back to that Proto-Oceanic etymon - are not always easy to detect; knowledge of regular sound change in Vanuatu is sometimes necessary to ascertain the exact list of words we want to examine.

While the present article was under revision, Marie-France Duhamel published an article on "the concept of taboo in Raga, Vanuatu" (Duhamel 2021), which originated in the same 2017 workshop as the present paper. This is a positive sign that the topic is being increasingly explored in non-Polynesian languages. 
MAP 1 - LANGUAGES OF VANUATU SHOWING REFLEXES OF *TABU, AND CITED IN THIS STUDY.

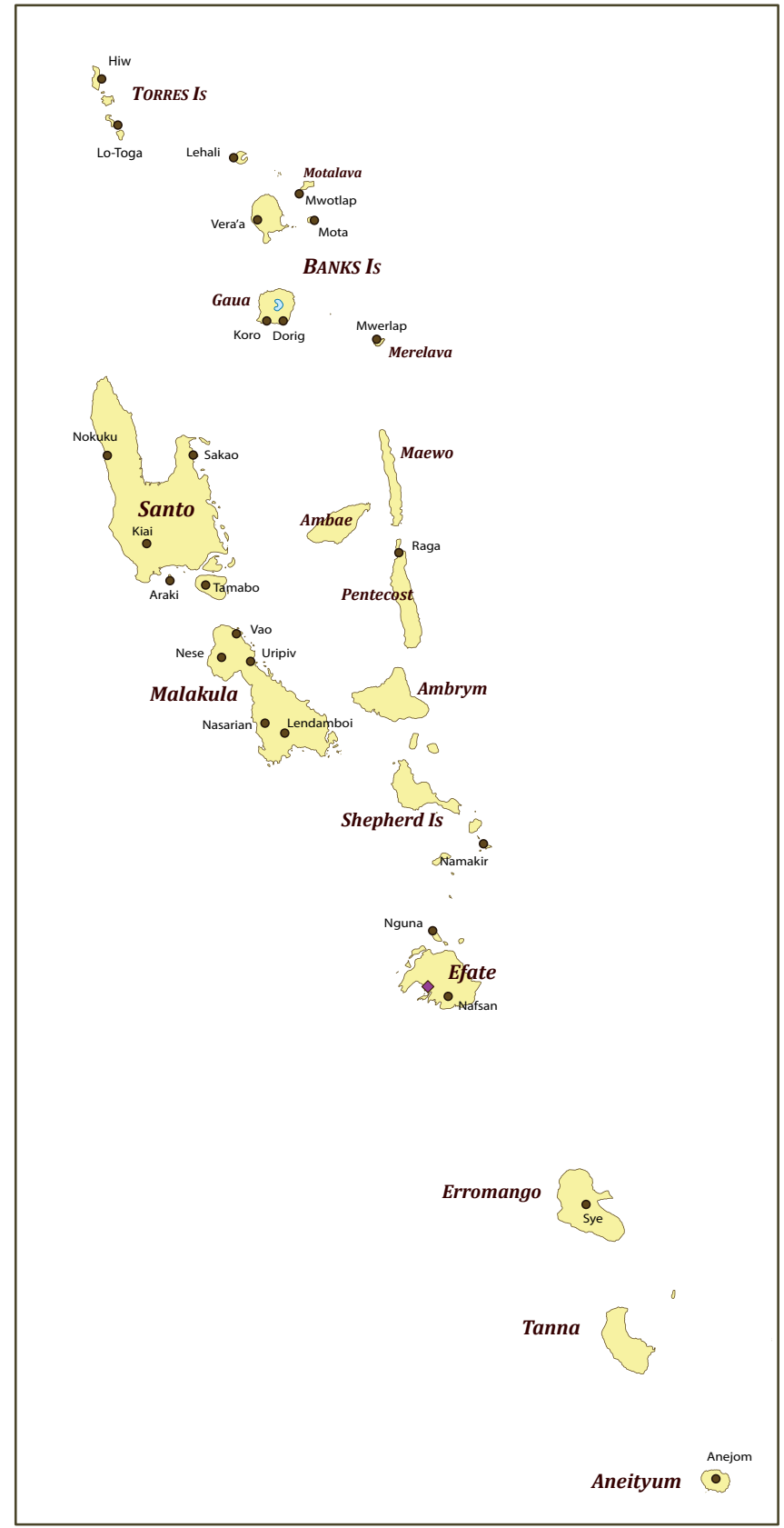


Once that target list is established, Section 3 will present their various meanings in the context of the social practices, ancient and modern, with which they are associated.

In order to make sense of the diversity of meanings attested, Section 4 will organize them into a semantic map. That map will then be useful to visualize the commonalities and differences among modern languages.

Finally, Section 5 will reconstruct the most likely meanings of *tabu at the time of Proto-Oceanic, based on a broader sample of languages. I will end this study by discussing semantic change and lexical replacement, as it can be reconstructed for various languages in the semantic domain of sacredness and prohibition.

I will show how Proto-Oceanic *tabu revolves around the notion of proscription, with two main facets: mundane acts of prohibition as a social practice; but also, religious types of proscription, linked to the awe-inducing presence of spiritual forces. In other terms - to answer our earlier question our empirical evidence will show that the religious undertones of $*$ tabu ought to be reconstructed all the way back to ancient Proto-Oceanic society.

This research will be conducted in the spirit of Dumézil (1958; 1995 [1968]) and Benveniste (1973), two scholars who used the insights of the linguists' comparative method to reconstruct the religion of ancient IndoEuropean societies. Works by Robert Blust (1980, 1981, 1987), or volumes by Ross, Pawley \& Osmond (1998-2016), have long established a similar scholarly tradition within the realm of Austronesian studies. The present paper will hopefully provide anthropologist readers with another illustration of how linguists can contribute, through methodical investigation, to the reconstruction of social practices and cultural representations of past millennia.

As for linguists, they will find here a discussion of historical semantics around a particularly polysemous etymon. I will make proposals for handling its evolving polysemy, through the use of lexical maps (François 2008, f/c; J. François 2013; Georgakopoulos 2019) - coupled with some key principles of the Comparative method. By combining etymology with visual representation, this paper offers an innovative approach to the analysis of semantic change.

2. CIRCUMSCRIBING THE SCOPE OF THIS STUDY. Before we proceed further, it is useful to circumscribe the exact scope of the present study. I will start with a brief note on kinship taboos in northern Vanuatu, and explain why they won’t be the object of our research here [\$2.1]. Our attention will rather focus on "*tabu words", i.e. modern words descended from the POc etymon *tabu - setting aside loanwords from Polynesian [\$2.2]. I will explain the methodological principles necessary to the identification of *tabu words notably, the regularity of sound change [\$2.3]. 
2.1 A NOTE ON LINGUISTIC TABOOS. Besides its common use in colloquial parlance, the English term taboo has also been employed in anthropology to refer to various cultural practices involving restrictions, whether religious or not (Steiner 1999 [1956], Blust 1981). Among these, the cultural practice of avoiding specific words in certain social contexts, known as linguistic taboo (Allan \& Burridge 2006, Pizarro Pedraza 2018), deserves a mention here, as this sort of practice is well attested in northern Vanuatu. I will briefly review them here, even though - as we'll see - they won't be our primary concern in this study.

One set of prohibitions include practices of tabooing certain words or names - as witnessed also in various other parts of the world. ${ }^{4}$ Contrary to Tahitian pi' $i$ which entailed the ban of certain words for entire communities (Ahnne 1994 [1917], Vernier 1948), the naming taboos observed in Vanuatu are based on kinship relations, and thus affect each person differently.

Those taboos are usually related to affine (in-law) relations. ${ }^{5}$ I'll cite three linguistic prohibitions I observed firsthand in the Banks and Torres Islands:

1. In the central Banks (Vanua Lava, Motalava, Mota), I am forbidden from uttering in public the names of an in-law, or even a word that sounds similar to it; ${ }^{6}$ I must instead use an avoidance strategy (e.g. employ a kin term, a synonym, a periphrasis).

2. I am encouraged to use honorific dual in lieu of singular, when addressing ( $2^{\text {nd }}$ person) or mentioning ( $3^{\text {rd }}$ person) an in-law. ${ }^{7}$

3. In the Torres Islands, I am encouraged to use a special lexical register, perceived as more respectful, in a sentence addressing or mentioning an in-law.

While these practices could indeed be described in English as linguistic taboos, they are never labelled locally using reflexes of the Oceanic root*tabu. Instead, northern Vanuatu languages use words meaning 'avoidance':

- the language Mwotlap (Banks Is) has the noun na-plig /napliy/ '1) avoidance; 2) hence social practice whereby one avoids uttering publicly the names of in-law relatives' - from a verb /viliy/ 'avoid, refrain from' (François 2020:322);

- Hiw (Torres Is) has mañe visevise /mayə ßisəßisə/ [liter. 'avoidance speech']: 'respectful speech register used for showing respect to one's in-laws' </ßisə/ 'avoid, make a detour' (François 2011:207).

4 See Stasch (2011) on New Guinea; Dixon (1990) on Australia; Herbert (1990) on southern Bantu; Treis (2005) on Ethiopia.

5 In the Banks and Torres Islands, the set of in-law relations linked with prohibitions include my spouse's parents; my spouse's opposite-sex siblings; my opposite-sex siblings' spouses; and my children's spouses. By contrast, taboo practices do not concern the same-sex siblings of my spouse (wife's sister, husband's brother), or the spouses of my same-sex siblings (brother's wife, sister's husband).

6 See Codrington (1891:44) on Mota, Malau (2016:12-14) on Vurës.

7 See Codrington (1891:45) on Mota, François (2001:388, 2005b:121) on Mwotlap. 
Despite their interest for an anthropological exploration of taboos in Melanesia, these social practices will not concern us here. Instead, I will focus on those concepts of Vanuatu cultures that are expressed using reflexes of the POc root *tabu. As we shall see, these do include various forms of prohibitions (whether related to land use, to ascetic rituals during male initiations, to gender relations, or to funeral ceremonies); yet these restrictions are linked neither to language behaviour, nor to kin relations.

2.2 BORROWINGS FROM POLYNESIAN TAPU. As we set out to study the semantics of *tabu words outside Polynesian languages, we should start by briefly mentioning the special case of Polynesian borrowings.

The pidgin-creole Bislama - now the lingua franca of Vanuatu - commonly uses Tapu! as an interjection; it is uttered by parents to toddlers as a general prohibition 'Don't [do that]! Stop!' It likely reflects a borrowing from a Polynesian language - though the source is unclear. The interjection is sometimes heard in the vernacular languages too, in the same context - usually as an instance of codeswitching with Bislama (cf. Duhamel 2021:31).

Another question is whether Polynesian tapu has been borrowed into the lexicon of non-Polynesian languages, independently of Bislama. I haven't found any evidence of such borrowings in Vanuatu languages. All the forms we'll discuss in this study descend from *tabu directly from Proto Oceanic rather than via Polynesian; indeed, as we'll see [\$2.3], they reflect the expected sound changes that would have affected a root $* / \mathrm{ta}^{\mathrm{m}} \mathrm{bu} /$ from POc, rather than a recent borrowing from tapu.

This is not to say that such borrowings have not occurred at all in Island Melanesia, though. One good example is Teanu, the main language of Vanikoro (François 2009, 2021b) in the Temotu province of the Solomons close to northern Vanuatu. This language has been in sustained contact with two Polynesian outliers, namely Tikopia and Vaeakau-Taumako.

Teanu has a form etapu, which is clearly borrowed from Polynesian e tapu ('is forbidden...'), coalesced into a single word. In Teanu, this loan has several meanings. It can be used as an adjective 'unapproachable, forbidden':

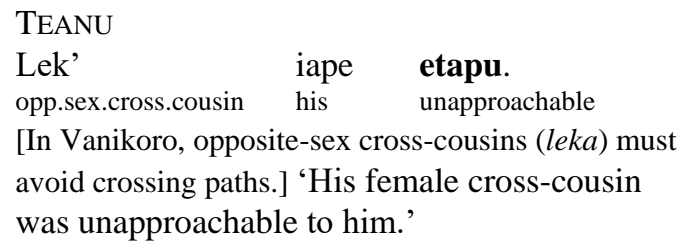

Etapu also means 'sacred, holy', either in a pre-colonial context or in a Christian interpretation [see \$3.2.1]:

8 The link https://doi.org/10.24397/pangloss-0003352\#S68 provides direct access to the sentence whence this example is taken, including the audio. 
(2) Temaka etapu, temaka pe li-tamava ene. place sacred place rel 3pl-worship anaph 'A sacred place is one where rituals are performed.' [Tnu.IP1-05b]

(3) Enga eo etapu.

name your sacred

'hallowed be Thy name' [Tnu.Father.02]

Along with those lexical senses, Teanu has also grammaticalized etapu as a general prohibitive marker:

(4) U-madau etapu.

2s:Irr-fear PROH

'Don't be afraid!'

[Tnu.Treasure.07] ${ }^{9}$

Such grammaticalization, from an adjective meaning 'unapproachable' or 'holy' to a general prohibitive, illustrates what can be described as the "secularization" of the root *tabu - as we also saw for Bislama. These illustrate a mundane sense 'forbidden', that can apply to just any action.

While such borrowings are instructive in themselves, it is unclear if their polysemy was inherited from Proto-Oceanic or from their Polynesian source, or if it reflects a local development. For example, the general meaning of prohibitive is sometimes reported for Polynesian languages (Bender \& Beller 2003), but it does not show up in non-Polynesian languages of Vanuatu. Likewise, the dimension of kinship illustrated in (1) was only found in Teanu, and not observed in other non-Polynesian languages.

Considering we wish to explore the semantics of *tabu outside Polynesian, it is thus methodologically cautious to concentrate on forms that are not borrowings, but directly inherited from their Oceanic ancestor.

\subsection{REGULAR SOUND CHANGE, A KEY FOR IDENTIFYING THE} PROPER REFLEXES. Since the times of Proto-Oceanic, many words have gone through drastic change both in form and in meaning, making them at times difficult to identify. It may therefore be useful to explain our method for detecting with confidence the target words of this research. For example, Mwotlap has a verb /tam/ 'respect', and a noun /nctek $\widehat{p}^{\mathrm{w} /}$ 'graveyard': do they both reflect POc *tabu? or is only one of these two words a suitable candidate and if so, which one?

The Proto-Oceanic root *tabu can be reconstructed based on reflexes in a large number of Oceanic languages. Thus Blust \& Trussel (2021) reconstruct a POc etymon of the form $* / \mathrm{ta}^{\mathrm{m}} \mathrm{bu} /($ spelled $* t a b u)$, with a prenasalized bilabial $/ \mathrm{m} \mathrm{b} /$; and assign it the meaning 'forbidden, taboo'. (They also propose an earlier etymon tambu at the level of PCEMP, with the same gloss.) In many conservative languages, the root is easy to recognize, both in its form or meaning. These authors cite Gela (Solomons) tambu 'forbidden, taboo, sacred+'; or Wayan Fijian tabu 'forbidden, prohibited; sacred, holy'.

9 Audio link: https://doi.org/10.24397/pangloss-0003269\#S7. 
There is discussion whether the POc etymon should be reconstructed with a final consonant, that would have been retained in a handful of modern Oceanic languages yet lost everywhere else. Blust (1978:216) once proposed to reconstruct *tabus for the level of PEMP (Proto Eastern Malayo-Polynesian), an ancestor of POc. As far as Vanuatu is concerned, Lynch (2001:302) reconstructs *tabur for Southern Vanuatu, based on such forms as tompor 'holy, sacred' in Sye (Crowley 2000:137); supporting evidence from Malakula includes Nasarian na-tambor a and Lendamboi $a$-tamboro, both meaning 'tomb' (Charpentier 1982: 2.1.7). ${ }^{10}$ A putative etymon $* / \mathrm{ta}^{\mathrm{m}} \mathrm{bur} /$ is not implausible: knowing that all other languages of north-central Vanuatu have regularly lost POc final consonants, they would regularly reflect that protoform as $* / \mathrm{ta}^{\mathrm{m}} \mathrm{bu} /$ anyway. Yet knowing that Oceanic languages sporadically insert non-etymological consonants to their word endings (see Evans 2003:220), it might be the case that the final *r results from a local development. Based on such a small set of reflexes, it is difficult to reconstruct a final consonant all the way to POc.

In the remainder of this paper, I will follow common usage (e.g. Blust \& Trussel 2021, Clark 2009:186) and refer to the etymon simply as *tabu.

Among the 138 Oceanic languages that are spoken in Vanuatu (François et al. 2015), Map 1 [\$1.2] showed those that are cited in the present study. These languages vary in how drastically they have been affected by sound change since their reconstructed POc ancestor. Conservative forms include tapu 'taboo, proscription, forbidden...' in Kiai (Santo) (Clark 2009:186-7) - which is unproblematic in form and meaning.

By contrast, it takes more effort to realize that etev 'burial ground, grave' in the Sakao language of Santo I. is also a reflex of the same root $* / \mathrm{ta}^{\mathrm{m}} \mathrm{bu} /$. This is less easy to detect, due to the changes in meaning as well as in phonological form: /etev/ shows loss of the etymon's final vowel; change of the stressed vowel *a > /e/ by umlaut (Guy 1977); lenition of the stop *mb to a fricative /v/; and morphological accretion of the V-article to the word (cf. Touati 2015): $* /(\mathrm{n})$ a ta ${ }^{\mathrm{m}} \mathrm{bu} />* / \mathrm{a}-\mathrm{tá} \beta \mathrm{u} />* /$ - $\mathfrak{2} \beta />/ \varepsilon t \varepsilon \beta /$. Yet all these changes can be shown to be regular in the phonological history of Sakao.

And indeed, this principle of regular sound correspondences provides the key to identifying with certainty the reflexes of a particular protoform.

The initial consonant $* \mathrm{t}$ remained $/ \mathrm{t} /$ in most Vanuatu languages, yet it changed to $/{ }^{\mathrm{n}} \mathrm{d} /$ in Namakir $\left(* / \mathrm{ta}^{\mathrm{m}} \mathrm{bu} />/{ }^{\mathrm{n}} \mathbf{d a m} /\right.$ ) and to a trill $/ \mathrm{r} /$ in Araki: $* / \mathrm{ta}^{\mathrm{m}} \mathrm{bu} />$ /rapu-/. This change is systematic in Araki: e.g. *tama- > /rana/ 'father'; *tani(s) > /rani/ 'weep'; *toka > /roho/ 'stay', etc. (François 2002). In Vera'a, *t is usually reflected by a glottal stop / $\mathrm{R} /$ (François 2016:31): thus a reflex of $*$ tabu is a form $/ \mathbf{2} \mathrm{u}^{\mathrm{m}} \mathrm{bu} /$ [see $\left.\$ 3.1 .2\right]$.

Duhamel (2021) provides a detailed discussion of a term sabuga /sambuya/ in Raga. She follows Clark (2009:186-7) in seeing it as a reflex of *tabu, in

10 I am grateful to John Lynch (pers. com.) for directing me towards these two forms. 
spite of the word's unexpected form (irregular change $* t>/ s /$, unproductive suffix /-ya/). The present study will follow Duhamel and Clark's proposal, and present $/ \mathrm{sa}^{\mathrm{m}}$ buya/ as a reflex of *tabu. Note however that neighboring Apma has a form sambak 'forbidden, sacred; holy; virgin' (Gray \& Temwakon 2012) which is most probably cognate with Raga sabuga, but less likely to be a reflex of *tabu. This suggests sabuga might reflect a different etymon after all.

Many North Vanuatu languages went historically through a change in phonotactics, as a sequence of two open syllables ${ }^{*} \mathrm{C}_{1} \mathrm{~V}_{1} \mathrm{C}_{2} \mathrm{~V}_{2}$ lost its final vowel, and changed to a closed syllable $/ \mathrm{C}_{1} \mathrm{VC}_{2} /$. Hence $* / \mathrm{ta}^{\mathrm{m}} \mathrm{bu} />* / \mathrm{ta}^{\mathrm{m}} \mathrm{b} \# />$ (Dorig) /ta: ${ }^{\mathbf{m}} \mathbf{b} /$, (Mota) /tap/, etc. In many languages, the new coda position led the prenasalized stop to deoralize (François 2016:31). This regular change $*_{-} \mathrm{m} b>/-\mathrm{m} /$ is reflected in Koro /tॄâm/, Mwerlap /no-tom/, Namakir /ndam/.

In the northernmost islands, a rounded vowel tended to assimilate a preceding bilabial stop, adding to it a labio-velar release: $* / \mathrm{mbu} />* / \mathrm{m} \mathrm{b}^{\mathrm{w}} \mathrm{u} /$. The complex segment then became both velarized and devoiced: $* / \mathrm{m} \mathrm{b}^{\mathrm{w} /}>* / \mathrm{mm} \mathrm{gb}^{\mathrm{w} /}$ $>/ \mathrm{k}^{\mathrm{w}} /$. This is how, for example, Mwotlap regularly reflects the noun */na ta ${ }^{m} \mathrm{bu} /$ (with article *na) as modern /nc-tek $\widehat{\mathbf{p}}^{\mathrm{w}} /$. The two Torres languages later delabialized their labial-velar phonemes, yielding a $/ \mathrm{k}^{\mathrm{w}} /$ segment: this is how the regular reflex of $* / \mathrm{ta}^{\mathrm{m}} \mathrm{bu} /$ in Hiw and Lo-Toga is a form $/ \mathrm{tok} \mathbf{w}^{\mathrm{w}} .{ }^{11}$

In the whole area, the process of final-vowel apocope was preceded by a change in the quality of the preceding stressed vowel, in a general process of umlaut or metaphony (François 2005a). A sequence *áCu in POc (where C represents any consonant) yielded vowel reflexes that differed across languages, yet were regular within each language. Compare the reflexes of */tám ${ }^{b u /}$ in a selection of Torres and Banks languages (arranged here in a northwest to southeast order) with the reflexes of a similar etymon, */páRu/ 'hibiscus' (François 2013:192):

*tabu $/ \mathrm{ta}^{\mathrm{m}} \mathrm{bu} /$ 'forbidden, taboo+':

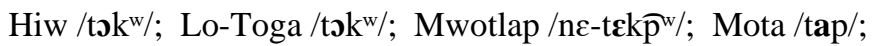

Dorig /ta: ${ }^{\mathrm{m} b} /$; Koro /tæâm/; Mwerlap /no-tom/.

(6) *paRu 'hibiscus':

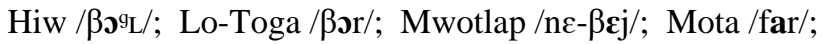

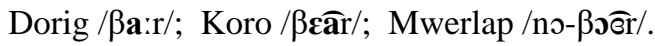

The reliance on regular sound change is an important principle inherited from the Comparative method. Thanks to this principle, we can be confident that, for example, the form /nc-tekp ${ }^{\mathrm{w}} /$ qualifies as a reflex of $* / \mathrm{ta} \mathrm{m}^{\mathrm{m}} \mathrm{bu} /$, because the sound changes it reflects are all regular in Mwotlap - including the velarization $* / \mathrm{mb} />* / \mathrm{m}^{\mathrm{w}} />/ \mathrm{kp}^{\mathrm{w}} /$ before a rounded vowel, or the particular pattern of metaphony (umlaut) whereby *áCu is always reflected by $/ \varepsilon /$.

11 For a similar example, the POc etymon * $\mathrm{tu}^{\mathrm{m}} \mathrm{bu}-$ 'grandparent' is reflected as /tupu-/ in Mota, $/ \mathrm{tu}^{\mathrm{m}} \mathrm{bu}-/$ in Koro, / $\mathrm{t}^{\mathrm{m}} \mathrm{bu}-/$ in Dorig, / $\mathrm{Pu}^{\mathrm{m}} \mathrm{bu}-/$ in Vera'a... - but as /itk $\widehat{p}^{\mathrm{w}} \mathrm{u}-/$ in Mwotlap, and $/$ tukw u/ in Lo-Toga (François 2005a:501). 
This criterion is helpful not only in identifying positive reflexes, but also in ruling out tempting yet false candidates. For example, Mwotlap has a verb /tam/ meaning 'love, esteem, respect'. At first glance, a form like / tam/ might have looked like a possible reflex of $* / \mathrm{ta}^{\mathrm{m}} \mathrm{bu} /$, since we saw that syllable-final $* \mathrm{~m} b$ is often reflected as $/ \mathrm{m} /$; as for its meaning, it wouldn't be implausible for a word meaning 'respect' to have some semantic relation with 'forbidden, taboo' - which would have shed light on the semantic evolution of *tabu words. However, this hypothesis can be disproven in this case, by taking regular correspondences into account. In Mwotlap, a vowel /a/ never reflects a sequence *áCu; it can only have its origin in a sequence *áCe, *áCa, or *áCo (François 2005a:490).

As far as this word /tam/ is concerned, comparison with Hiw /tep/ or Vurës /tiam/ (same meaning), combined with knowledge of regular vowel correspondences in the region, allow us to reconstruct with confidence a protoform $* / \mathrm{ta}^{\mathrm{m}} \mathrm{be} /$ rather than $* / \mathrm{ta}^{\mathrm{m}} \mathrm{bu} /$ :

(7) *tabe "to love, esteem, respect" > Hiw tep; Lo-Toga tep; Mwotlap tam; Lemerig ?ap; Vurës tiâm ...

This is in fact the same etymon as the *tabe 'love, honour' reconstructed by Clark (2009:186) based on languages further south. This *tabe might be a metaphorical extension of another verb *tabe 'lift, raise' (ibid.); at any rate, it is unrelated to *tabu.

By applying this principle of regular sound correspondences, it is possible to identify with certainty reflexes of *tabu in 25 languages of Vanuatu [Map 1]; the relevant forms are listed in the Appendix [\$7.2]. As regards other languages of the archipelago, I consulted various lexicographic sources (Lynch 1977 for Lenakel; Crowley 2006b for Tape; Guérin 2009 for Mav̈ea; von Prince 2017 for Daakaka; Malau f/c for Vurës; ...), yet have not identified any reflex of *tabu in any of them. In some cases this may be caused by limited data; but this may also be due to the actual loss of that etymon from modern lexicons, resulting from historical processes of lexical replacement [§4.3]. Several publications discussing taboo-like concepts in parts of Vanuatu (e.g. for Pentecost: Jolly 1996 on Sa; Duhamel 2021 on Raga) cite modern words for 'taboo' whose etymology reflects a different root, such as *kona or *rono. In spite of their interest, such forms fall outside the scope of the present study, which is exclusively concerned with reflexes of *tabu.

3. THE MEANINGS OF *TABU REFLEXES IN VANUATU. Now that we have secured our list of relevant forms (and ruled out deceptive candidates), we can proceed to an analysis of their modern meanings.

From this point onwards, each new sense we identify of *tabu reflexes will be identified by a number (meaning 1 , meaning $2 \ldots$ ); this will be useful when we draw semantic maps in our final discussion [Sections $4 \& 5$ ]. 


\subsection{PROSCRIPTION AND BAN}

3.1.1 Forbidden. Reflexes of *tabu in modern languages are sometimes used as adjectives, sometimes as verbs, and sometimes as nouns. If we first examine the reflexes used as adjectives, ${ }^{12}$ a widespread meaning is "(place, thing) off limits, unapproachable, forbidden":

*tabu > MEANING 1 "(place, thing) off limits, unapproachable, forbidden": Hiw toq; Lo-Toga toq; Lehali tpu; Mota tapu 'taboo, unapproachable, not to be touched'; Raga sabuga; Tamabo tambu 'forbidden'; Namakir daka-tam; Nafsan tap.

In spite of the English translation as 'forbidden' or 'prohibited', adjective-like reflexes of $*$ tabu in Vanuatu normally do not refer to the trivial sense of the word - as when someone, e.g. a parent, prohibits a certain action to their children. Rather, reflexes of *tabu generally entail an aura of spiritual significance: if a place or thing is *tabu 'forbidden, unapproachable', that is usually because they are associated with magical or spiritual forces. We will come back to these meanings ('sacred, holy...'), as they are central to the whole family of meanings associated with reflexes of *tabu.

That said, the secular, mundane interpretation 'forbidden [of any action]' is not entirely absent from *tabu reflexes in Melanesia. This is particularly the case, as we'll see now, with transitive verbs derived from *tabu.

3.1.2 Setting up a ban. In some languages, the root *tabu can be directly used as a causative verb, meaning 'make s.th. forbidden, prohibit':

(9) *tabu > MEANING 2 "[V] prohibit, set apart": Mwerlap tom.

Other languages, though, combine the radical with derivational affixes. For example, Mota encodes this meaning using a derived form tapug /tapu- $\mathrm{\gamma} /$ '[v.] to make tapu; [n.] a mark of tapu' (Codrington \& Palmer 1896:199).

Other North Vanuatu languages render the causative meaning as *tabúa. The latter form is not attested as such, but it can be computed thanks to the Comparative method and to regular sound correspondences. Indeed, such modern forms as Mwotlap tōqō /tøk $\widehat{p}^{\mathrm{w}} \mho /$ or Vera'a 'ubu(ō) / $\mathrm{Pu}^{\mathrm{m}} \mathrm{bu} \sim \mathrm{Pu}^{\mathrm{m}} \mathrm{bu \mho} /$ point to a trisyllabic etymon *tabua:

$$
\begin{aligned}
& * \text { tabu } \rightarrow \text { *tabu-a }>\text { MEANING } 3 \\
& \text { "[V] ban access to a place by standing up a conventional sign": } \\
& \text { Mwotlap } t \bar{q} q \bar{o} \text {; Vera'a 'ubūo 'put up a ban (on an area)'. }
\end{aligned}
$$

This reconstruction will be confirmed by the Mota form tapua in (14). The final (reconstructed) vowel in *tabúa points to a fossilized $3 \mathrm{sg}$ suffix $-a$.

The type of prohibition mentioned here does not imply any form of sacredness. Banning access to an area using a conventional sign is a regular

12 Torres-Banks languages have a category of adjectives that is distinct both from nouns and from verbs: see François (2003:48-53) for Mwotlap, Malau (2016:118) for Vurës, François (2017) for Hiw. 
practice that people carry out when they wish to indicate ownership of a place - typically, a house, a garden (11), a fishing spot on the reef (12), or a group of trees (13), that they wish to reserve for themselves. These examples are from my Mwotlap (Mtp) and Vera'a (Vra) corpora:

(11)

$\begin{array}{llllll}\text { MwOTLAP } & & & \\ \text { No } & \text { mal } & \text { tōqō } & \text { mahē } & \text { gōh } & \text { kēe } \\ \text { 1sg } & \text { CPLT } & \text { ban } & \text { place } & \text { this } & \text { here }\end{array}$

n-et tit-kalbat vēhte.

ART-person NEG:POT 1 -enter NEG:POT 2

'I've put up a ban on this place,

nobody can come in.'

[Mtp.Wild-boy.063] $]^{13}$

(12) MwOTLAP

Ige mal tōq $\overline{\mathbf{o}}$ nē-n̄ēlmet.

people CPLT ban ART-reef

'They've put up a ban on the reef.'

[Mtp.AP2-184]

(13) VERA'A

Maro-mrūo ga 'ubu gōr ēn= 'uvu ñar.

uncle-2du STAT ban (prevent) ART= tree Canarium

'Your uncle has put a ban on the Canarium trees.' [Vra.Cave.03] ${ }^{14}$

The way such bans are announced is by means of a conspicuous sign made of a leaf (e.g. a coconut palm, cycas palm, or cordyline leaf) that the owner puts up at the entrance of the area in question for everyone to see. By metonymy, the verb *tabu or its derivative is sometimes converted to a noun to refer to the (abstract) ban, or to the actual sign itself:

(14) *tabu $\rightarrow$ *tabu-a > MEANING 4 "[N] a ban imposed on a given area; a sign set up to make that ban known": Mwotlap na-tqō; Mota tapua 'a thing or place made taboo; a mark or sign set up'.

Figure 1 is a picture of such a ban sign (Mtp na-tqō [nat $\left.\widehat{\mathrm{kp}}^{\mathrm{w}} \mathrm{v}\right]$ ), made of a wooden stick wrapped in coconut leaves. This sign was set up on a rock above the lagoon of Motalava island, with the effect of prohibiting all fishing activities in the area, so as to allow fish to reproduce for a period.

The two Torres languages have lost trace of any causative verb, but have a noun that also points to a protoform *tabua. These nouns refer to the enclosure dedicated to men's initiation rituals:

$*$ tabu $\rightarrow$ *tabu-a $>$ MEANING 5 "[N] an area or enclosure with restricted access; espec. enclosure reserved for men's initiation rituals": Hiw teqö; Lo-Toga teqe.

The semantic link between (10), (14) and (15) is one of metonymy: first, a metonymy between the action 'to ban access' and the sign used to indicate that

13 Audio link: https://doi.org/10.24397/pangloss-0007411\#S63.

14 Audio link: https://doi.org/10.24397/pangloss-0003326\#S3. 
ban; second, a metonymy between such an action and a special area or enclosure affected by that restriction, in a religious context. As we will see in $\S 3.2 .2$, Torres languages indeed strongly associate the root *tabu with initiation rituals.

\section{FIGURE 1 - A 'TABOO' SIGN MEANT TO BAN FISHING ACTIVITIES}

IN THE LAGOON FOR A PERIOD. (photo: A. François, 2011)

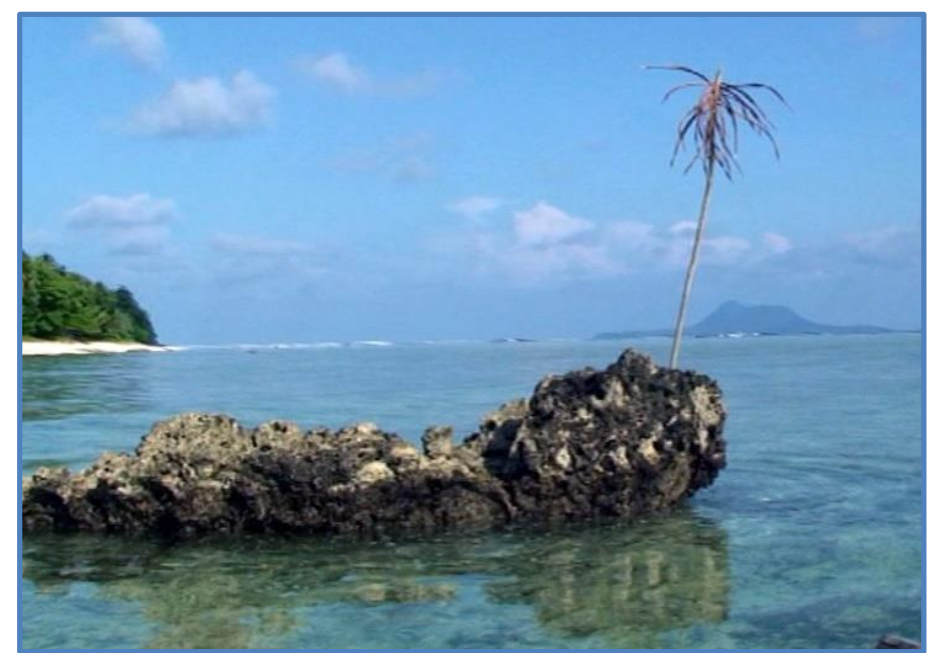

3.1.3 Forbidden mention. One particular type of prohibition is one that prevents speakers from mentioning a particular topic of conversation. This is the sense closest to taboo in modern English:

(16) *tabu > MEANING 6 "[ADJ] taboo, not to be mentioned lightly in public": Hiw toq; Lo-Toga toq; Lehali tpu; Dorig tāb; Koro täm.

This sense is illustrated by this sentence in Lo-Toga:

(17) Lo-ToGA

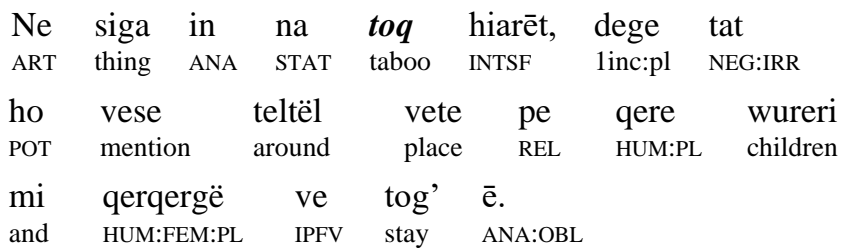

'This topic is extremely taboo, you can't just mention it lightly when you're surrounded by [Ltg.q06:18] children and women.'

3.1.4 A ban against evil spirits. Durand (2014) reports on a special kind of ban found in the culture of Merelava (Banks Is.). In the Mwerlap language, the noun no-tom /no-tom/ ( $<* /$ na ta $\left.{ }^{\mathrm{m}} \mathrm{bu} /\right)$ refers to a conventional sign made with 
certain plants of high symbolic power: Ficus wassa, Cycas seemannii, Codiaeum variegatum.

Besides its ordinary use as a sign for banning, say, fishing activities (cf. Figure 1 above), a no-tom sign - "a taboo post" in Durand's terms - is also put up at the entrance of a house in order to deny access to undesirable guests. In particular, it will be erected at the door of a woman who just gave birth, so as to keep evil spirits from snatching the soul of a newborn baby (Durand 2014:102). Durand also reports (p.108) on the use of similar signs during wedding ceremonies, as a token of protection for the future marriage. This brings up a new meaning for a reflex of *tabu:

(18) *tabu > MEANING 7 “[n] a sign meant as a protection against ghosts and spirits": Mwerlap no-tom.

In this particular case, the prohibition is directed at the spirits themselves, who are banned from entering an area reserved for humans. This is an unusual configuration, considering how often - as we shall see now - the order is opposite: in most cases, the area which is *tabu is the one characterized by the presence of spirits, while mere mortals are usually the ones meant to keep away from it.

\subsection{SACRED, SUPERNATURAL, INITIATED}

3.2.1 The two poles of sacredness. We just saw a few examples in which reflexes of *tabu encode interpretations of 'forbidden, prohibit' that can apply to any context, including profane. However, those mundane uses are in fact a minority: most of the time, the prototypical meaning of *tabu has religious implications.

If things or places are unapproachable, this is often due to the presence of supernatural forces. Thus one of the prominent senses of *tabu is 'haunted':

*tabu > MEANING 8 "(place) haunted by ghosts or spiritual forces": Hiw toq; Lo-Toga toq; Lehali tpu; Mota tapu 'unapproachable, under a prohibition with the sanction of some mana belonging to men' (Codrington \& Palmer 1896:199)

The following sentence refers to those places in the island - the bush, the rocks - where spirits are believed to dwell (see François 2013:224):

(20) HIW

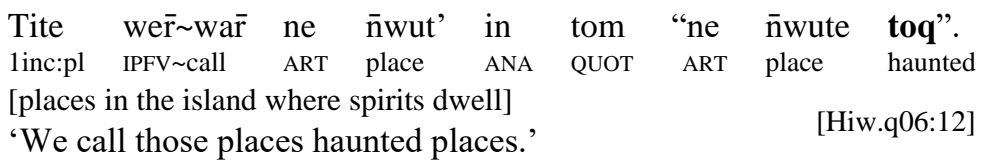

What makes such places unapproachable is not that they are revered or worshipped, but that they are feared. People carefully avoid coming close to such haunted places, for fear of having their souls snatched by evil spirits. In this context, reflexes of *tabu are better translated as 'haunted' or 'dangerous'. 
In some languages, the same root *tabu refers to what is 'sacred' or 'holy':

*tabu > MEANING 9

"sacred; numinous, endowed with spiritual or divine presence":

Hiw toq; Lo-Toga toq; Raga sabuga; Tamabo tambu 'sacred'; Vao tamp 'sacred'; Namakir dam 'holy'; Nguna tapu 'holy, sacred'; Anejom itẫ 'holy, sacred, taboo'.

Certain caves or stones in the wilderness are believed to be endowed with supernatural powers (Figure 2 p.21); they would be used as an altar to perform sorcery. The Torres languages have special names for those stones, ${ }^{15}$ but occasionally describe them with the adjective toq $(<*$ tabu) 'haunted' or 'sacred' - e.g. Lo-Toga ne vot toq 'sacred stones'.

The same word toq 'sacred, haunted by spiritual presence' was adopted by Torres islanders to render the Christian interpretation of holiness [see also ex.

(3) above for Teanu]:

(22) HIW

$\begin{array}{llll}\text { ne } & \text { ya } & \text { në } & \text { toq } \\ \text { ART } & \text { name:2sg } & \text { STAT } & \text { holy }\end{array}$

'hallowed be Thy name'

[Hiw. Paternoster.01]

$\begin{array}{lll}\text { ne } & \text { gengon } & \text { toq } \\ \text { ART } & \text { food } & \text { holy }\end{array}$

[lit. the holy food] 'the Lord's Supper'

[Hiw.Religion.033] ${ }^{16}$

This semantic extension to Christian 'sacred, holy' is found in several languages scattered in Vanuatu:

(24) *tabu > MEANING 10 "sacred, holy, in the Christian sense":

Hiw toq; Lo-Toga toq; Raga sabuga (Duhamel 2021:28, 32);

Nese saburr; Nguna tapu; Nafsan tap. ${ }^{17}$

The word here does not imply danger or fear as in (20), but a sense of wonder in front of a godly presence. In both cases, a location or an object is endowed with a supernatural or spiritual force, whether it is seen as formidable and dangerous, or beneficial and protective. The ambiguity between the two senses of *tabu is reminiscent of the one found with English awe, a word that has connotations both of fear and of reverence.

In his linguistically informed reconstruction of Proto-Indo-European religion, Benveniste (1973) suggests that ancient IE languages regularly distinguished between two concepts of "sacred". Indeed, he notes the existence of a recurring semantic contrast in Avestan, Gothic, Latin and Greek (Benveniste 1973:445):

The name is tuye in Hiw, and tegar in Lo-Toga (François 2013:222, 239).

Audio link: https://doi.org/10.24397/pangloss-0003252\#S33.

17 While Thieberger (2011) does not list explicitly the Christian sense under the entry tap 'taboo, forbidden', he cites various compounds such as nasum̃tap [house holy] 'church', tustap [book holy] 'Bible', aliat tap [day holy] 'Sunday'. 
Book 6: Religion - Chapter 1: The "Sacred"

"The study of each pair - Av. spənta : yaoždāta (cf. also Got. hails : weihs);

Lat. sacer : sanctus; Gr. hierós : hágios - leads us to posit, for the prehistorical period, a notion with a double aspect: positive "what is charged with divine presence", and negative "what is forbidden for men to contact."

While Benveniste's description sheds light onto a semantic contrast that is attested in some ancient IE languages, it also helps us define two different potential types of sacredness - one "positive" and one "negative". While these are two distinct meanings, they tend to be colexified in several Vanuatu languages, under the same root $*$ tabu.

Roger Keesing, commenting on Polynesian languages, noted that tapu referred both to the "positive valence of sacredness" and the "negative valence of 'pollution' and interdiction" (1985:204); he proposed to encompass the two interpretations under a single translation "off limits", deliberately ambiguous. Evidently, his conclusions about Polynesian languages also apply to the languages of Vanuatu: the ambiguity between the two "valences" - positive or negative - of *tabu surely goes back to Proto-Oceanic [see §5].

To be precise, that ambiguity really concerns the pre-Christian religion of Vanuatu, and its manifestations in modern societies. As for the Christian interpretation of *tabu, it would select the "positive" interpretation of "sacred', as the feeling of fearsome awe tends to be downplayed in Christian rituals.

3.2.2 The ambivalence of spirits. The spiritual force that is entailed by the concept of *tabu is thus inherently neither positive nor negative. The same can be said of words referring to "spirits", which are also ambivalent between a positive and a negative interpretation. In many Vanuatu languages, the same word may refer to the awesome presence of godly ancestors, or to dangerous creatures that must be feared (Vienne 1984).

As far as northern Vanuatu is concerned, the most common generic term for "spirits" is a local etymon *?ata-mate 'dead person, ghost' (François 2013: 213-8); this etymology highlights the deep connection between spirits and death. Spirits represent the souls of the deceased, and are usually eager to bring more souls to their realm - including by murdering us, as recalled in numerous stories and myths. Yet this terrifying aspect of spirits - which warrants the reactions of fear and avoidance mentioned above - goes along with a sense of awe and respect towards their power and significance. After all, the ghosts of the deceased are none other than our ancestors, who built the world we live in, and whose aura continues to inhabit our landscapes. Dance and music, songs and poetry, myths and legends, wisdom and culture, are all understood to have been carried over from the world of spirits to the society of men (Codrington 1891, Vienne 1984, François \& Stern 2013:74 sqq.).

The ambivalent polarity of "spirits" is consistent with the semantic ambiguity of *tabu, which can designate something both as holy and as fearful. 
3.2.3 Links with initiation rituals. In northern Vanuatu, much of the cultural knowledge inherited from ancestral spirits is handed over from one generation to the other through the initiation rituals involving men. Those rituals include the learning of dances, songs and poetry, or the secrets involved in making the headdresses that represent the spirits themselves (Vienne 1996).

In the Torres islands, the root *tabu is precisely associated with the initiation rituals and ceremonies whereby male adolescents acquire the secret knowledge that will make them be seen as full adults.

*tabu > MEANING 11 "of restricted access, due to its association with initiation rituals or grade-taking ceremonies": Hiw toq; Lo-Toga toq.

Candidates for initiation spend a period of several weeks secluded in the forest, in a secret cabin or enclosure, so as to stay away from the gaze of non-initiates, particularly women and children. In Hiw, that enclosure is called teqö toq, literally 'sacred/secret enclosure':

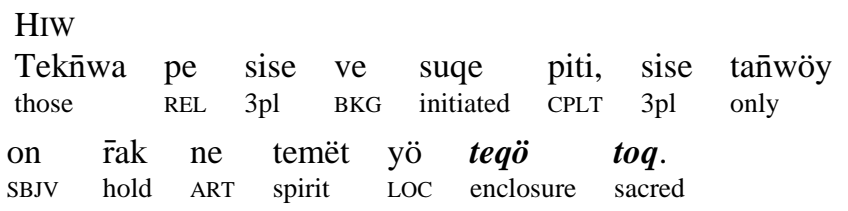

'Only those who have gone through initiation are entitled to handle spirits in the sacred enclosure.'

[Hiw.q06:17]

Interestingly, the word teq $\ddot{o} / \mathrm{t}^{\mathrm{k}} \mathrm{\textrm {w }} \mathrm{\Theta} /$ is itself etymologically derived from *tabu: see (15) in \$3.1.2. In other terms, the phrase teq ö toq in (26) reflects the root *tabu not just once, but twice: / $\mathrm{t}^{\mathrm{w}} \boldsymbol{\mathrm { w }} \mathrm{t} \mathrm{t}^{\mathrm{w}} /<* / \mathrm{ta}^{\mathrm{m}}$ búa támbu/ 'restricted-area that is sacred'.

One of the initiation rituals that candidates go through is called in Lo-Toga $n$ ' elevēn toq $/ \mathrm{n}=$ =ləßen tok $\mathrm{w} /$, literally 'the Sacred Journey', again with a reflex of *tabu. Codrington \& Palmer's Mota dictionary cites a number of phrases related to the rituals of suqe, which involve the word tapug /tapuy/ 'sacred, taboo' [\$3.1.2]: e.g. av-tapug ('sacred fire') $\rightarrow$ 'the fire belonging to each rank'; ime tapug ('sacred house') $\rightarrow$ 'the gamal [men's club house]'; gana tapug ('eat sacred') $\rightarrow$ 'consume the meals necessary for taking a step in rank'.

3.2.4 Going ascetic. During the process of initiation, the candidates must enter a period of ritual restrictions on food and sexual relations. Hiw calls these rites veyvoy / $\beta$ əj $\beta \supset \mathrm{j} /$ 'to abstain'; or vën teqtoq / $\beta \mathrm{en}$ tək ${ }^{\mathrm{w}}$ tok $\mathrm{k}^{\mathrm{w}} /$, which could be translated as 'to go ascetic'. The last word here, in adverbial position, is none other than the intensive reduplication of $*$ tabu: ${ }^{18}$

18 In the Torres languages, unstressed syllables regularly reduce to schwa [ə] (François 2005a: 466): hence $t o q / \mathrm{t} \mathrm{k}^{\mathrm{w}} /$ reduplicates as teqtoq $/ \mathrm{t}^{2} \mathrm{k}^{\mathrm{w}} \mathrm{t}^{\mathrm{o}} \mathrm{k} \mathrm{w} /$. 
$*$ tabu $\rightarrow$ reduplication *tabu-tabu > MEANING 12 "ascetic, complying with constraints associated with initiation rites":

Hiw teqtoq; Lo-Toga teqtoq.

Here is how Pastor Jimmy Tiwyoy of Hiw, in 2006, described these rites:

(28) HIW

$\begin{array}{lllllllll}\text { Sise } & \text { vën } & \text { teqtoq, } & \text { sise } & \text { veyvoy: } & \text { sise } & \text { tat } & \text { gon } & \text { ne } \\ 3 \mathrm{pl} & \text { go:PL } & \text { ascetic } & 3 \mathrm{pl} & \text { abstain } & 3 \mathrm{pl} & \text { NEG:IRR } & \text { eat } & \text { ART }\end{array}$

pēgone, sise tat vën yeqyōq mi tun̄wuyegë.

sea $3 \mathrm{pl}$ NEG:IRR go:PL random with HUM:FEM:PL

'Then they become ascetic, they go into abstinence.

They can't eat anything from the sea; and they [Hiw.Religion.053] ${ }^{19}$ cannot go around with women.'

Once again, the semantic shifts undergone by *tabu are noteworthy. The word may apply to a location or an object (e.g. a stone in the bush), and refer to the presence of a supernatural force. By metonymy, it may also designate an institutional location - the secret enclosure of initiation rituals - and describe it as 'sacred' by association with the religious rites that take place in it. Finally, the same word reduplicated refers to a certain behaviour linked with those rites: not a 'sacred' behaviour per se, but one that indicates piety and observance of religious rules.

3.2.5 Supernatural power. Another semantic extension of *tabu has to do, not with religious rituals strictly speaking, but with the supernatural power associated with chiefs of high rank in the ancient society.

This supernatural power is itself called mène/menə/ in Lo-Toga (Mondragón 2004, 2013) and mane /manə/ in Hiw (François 2013:237) - originally the same word as the mana of Mota $^{20}$ (Codrington 1891; Ivens 1931) and other Oceanic languages (Keesing 1984). Mana is a property not only of spirits and deities, but also of men of great wealth, which is a key condition in their access to political power (see Vienne 1984:377). Just like *tabu and *?atamate, *mana is in itself amoral, and non-polarized; its power can be put to bad use (e.g. witchcraft) or to good use (e.g. healing).

Now, the term *tabu is also heard in relation to the male-only political grade system known in the ethnographic literature as suqe (Codrington 1891, Vienne 1984, François 2013:234), and in Lo-Toga as huqe (Mondragón 2015). In those systems, so-called "great men" are assigned considerable mana; it is only expected that the adjective $\operatorname{toq}(*$ tabu) would be used in that context:

(29) Lo-TogA

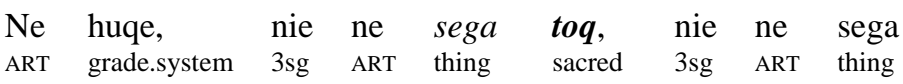

19 Audio link: https://doi.org/10.24397/pangloss-0003252\#S53.

20 The connection of *tabu with mana was already hinted at in the definition of Mota tapu as given by Codrington \& Palmer (1896) in (19) above. 


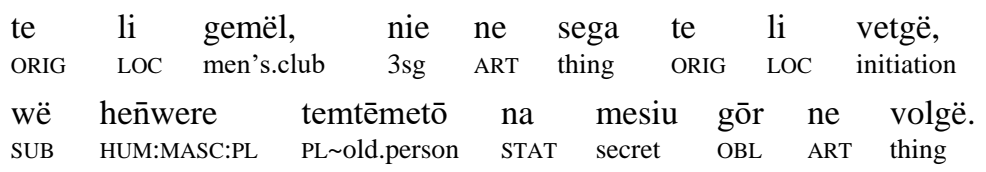

'The grade system is a sacred thing; it belongs to the men's club, it belongs to the initiation where the elders keep everything secret.'

In Hiw, *tabu is not only a characteristic of places or objects, but also, potentially, of an individual. A man will be a tayö toq /taje tok $\mathrm{w}$ / 'numinous person' if he shows to have magic, supernatural powers - such as the ones needed to become a man of high rank in the grade-taking system:

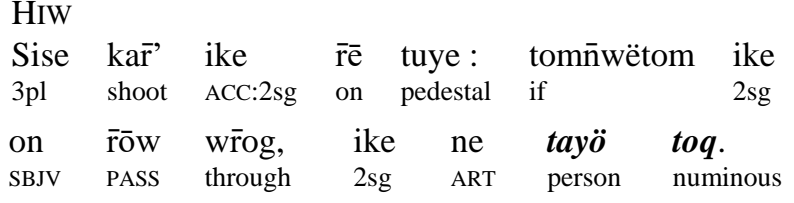

'People shoot [arrows] at you on the stone pedestal; in case you manage to survive, [this means] you are a supernatural man.'

[Hiw.Pedestals.11] ${ }^{22}$

In the Torres Islands, what I call here "stone pedestals" are known in Lo-Toga as dule /tstla/, and in Hiw as tuye /tuja/. These are three- to four-feet high sacred stones (Figure 2) that used to be erected at the entrance of men's houses - whether the entrance of the secret enclosure teq $\ddot{o}$ toq devoted to initiation rituals in the bush (26), or of the men's house (gemoy) in the village. These pedestals (François 2013:222) radiate with a numen that makes them both revered and feared - they are *tabu par excellence.

Now, what interests us here is the metonymic shift whereby a man becomes *tabu himself if he can show supernatural powers, in relation to that pedestal. One way to demonstrate this was for a young man to go through a ritual ordeal, where he'd stand on top of the pedestal while other men shot at him using sharp, poisoned arrows made of human bone (yiwe). The only way to avoid death was to dodge the arrows by jumping or dancing on top of the pedestal, without falling or getting hurt. Succeeding in that ordeal was taken as a sign of supernatural powers (mane < *mana), and the man was then considered a tayö toq, a 'numinous' person.

*tabu > MEANING 13 "[ADJ] 〈man〉 numinous, endowed with supernatural powers": Hiw toq; Lo-Toga toq.

21 Audio link: https://doi.org/10.24397/pangloss-0007303\#S3.

22 Audio link: https://doi.org/10.24397/pangloss-0007283\#S11. 
Note, in passing, that for a man to be considered 'numinous' in this sense, there is no need for chiefdom to be hereditary; we are dealing here with a grade system that is open - in principle - to any man in the community, based on his wealth (Vienne 1984). This may lead us to qualify the statement by Keesing (1992) cited in our introduction [§1.1], according to which the concept tabu in Island Melanesia "usually occurs without an association with hereditary chiefs and their sanctity and political power". Evidently, the association of $t a b u$ sacredness with highly ranked men is hardly restricted to Polynesian societies, and is also attested with non-hereditary chiefdoms of Island Melanesia.

3.2.6 Men of power. In line with the semantic shifts we just saw, the two Torres languages push the meaning of *tabu even further. The word is regularly associated with initiated men or men of power, even in the absence of a strong magical or supernatural component.

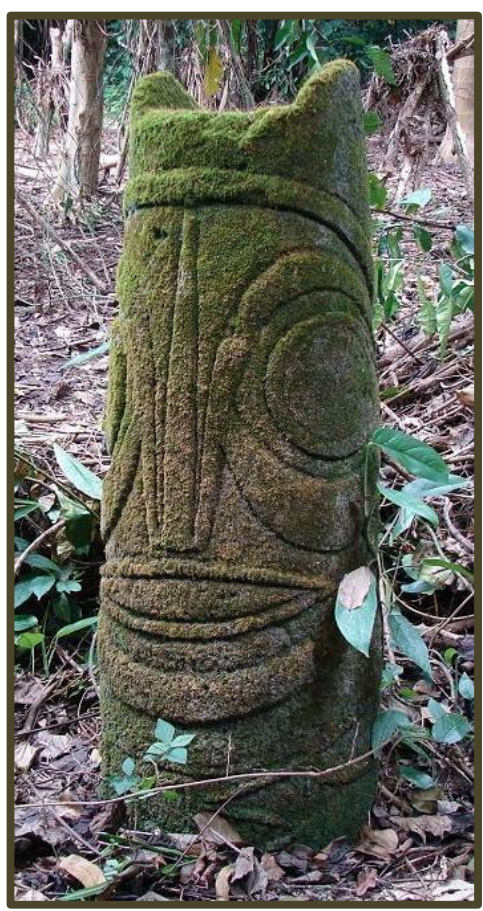

FIGURE 2 - A STONE PEDESTAL IN THE TORRES ISLANDS.

(photo: A. François, 2007)

For example, an area in the village will be considered 'sacred land' (vönyö toq) if it is restricted to initiated men, and forbidden to non-initiates:

(32) HIW

\begin{tabular}{|c|c|c|c|c|c|c|}
\hline $\begin{array}{l}\mathrm{Ne} \\
\text { ART }\end{array}$ & $\begin{array}{l}\text { qoō } \\
\text { mausoleum }\end{array}$ & $\begin{array}{l}\text { ve } \\
\text { IPFV }\end{array}$ & $\begin{array}{l}\text { toge } \\
\text { STAY }\end{array}$ & $\begin{array}{l}\text { takē } \\
\text { side }\end{array}$ & $\begin{array}{l}\text { vönÿ̈ } \\
\text { land }\end{array}$ & $\begin{array}{l}\text { toq. } \\
\text { sacred }\end{array}$ \\
\hline $\begin{array}{l}\text { Takē } \\
\text { side }\end{array}$ & $\begin{array}{l}\text { vönÿ̈ } \\
\text { land }\end{array}$ & $\begin{array}{l}\boldsymbol{t o q} \\
\text { sacred }\end{array}$ & $\begin{array}{l}\text { pe } \\
\text { FOC }\end{array}$ & $\begin{array}{l}\text { take } \\
\text { side }\end{array}$ & $\begin{array}{l}\bar{n} \text { nut } \\
\text { place }\end{array}$ & \\
\hline & ne & & $v \bar{e}$ & $\bar{Q}$ & & ye. \\
\hline REL & ART & 's.house & IPFV & lie: & & ANA \\
\hline
\end{tabular}

'Stone mausoleums [for high chiefs] were erected on sacred land. We call 'sacred land' the area around the house of initiated men.'

[Hiw.Religion.003] ${ }^{23}$

The beverage called kava (Piper methysticum) is reserved to men, and linked with the supernatural power (*mana) that characterizes men of power.

23 Audio link: https://doi.org/10.24397/pangloss-0003252\#S3. 
This explains why it may also be described as "sacred", as in this passage in Lo-Toga (mēne < *mana):

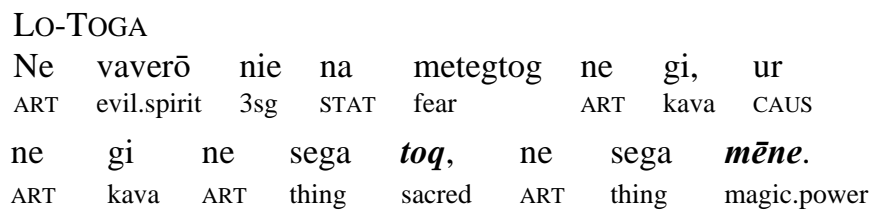

'Evil spirits are scared of kava

because it is a sacred thing, a thing of mana.'

[Ltg.FP1-26a]

And indeed, kava's secret name in Hiw, when using "avoidance speech" [\$2.1], is ne gë toq 'the sacred thing'.

Finally, some contexts in Hiw associate the reflex of *tabu with male gender in general:

(34) *tabu > MEANING 14 "(s.th.) restricted to men": Hiw toq.

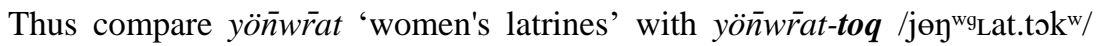
'men's latrines'. While the latter place is certainly not "holy" in any way, it still entails the notion of restricted access, as only men are welcome there. Admittedly, each of these locations (the one used by women, the other one by men) is forbidden to the other gender, and each could in principle be labelled "taboo" in that sense. It is significant that the one that gets to be called *tabu is the one linked with men - presumably due to the frequent association of that root with the world of male initiates.

3.2.7 Unapproachable woman. Most of the meanings we've examined so far, in which *tabu implied the presence of supernatural forces, were associated with the male gender; this tendency was especially conspicuous in the last examples.

Interestingly, Duhamel (2021:32) reports on a particular use of Raga sabuga, which is exclusively used with women. A woman becomes 'taboo' when she is in her menstruating period: she is then considered unapproachable to men, who should avoid getting close to her. In older times, menstruating women would seclude themselves in a menstrual house outside of the village (Taylor 2008:164-166 ; Yoshioka 1994:89-91). Today, a woman may say nam sabuga 'I am unapproachable' to state that she has her period, and that men should avoid interacting with her for fear or becoming sick. While other languages are reported to lexify the same meaning [see Sye mentioned in §4.3], Raga is the only language which associates it with the root *tabu:

*tabu > MEANING 15 "[ADJ] 〈woman〉 off limits to men, due to menstruating": Raga sabuga.

Duhamel interprets this meaning as implying that menstruating women are "endowed with powers relating to non-human beings". This can be understood 
as parallel to the sense we had identified earlier for the other sex - namely \#13 '〈men〉 numinous, endowed with supernatural powers'.

3.3 FUNERAL PRACTICES. Finally, we have seen several examples where a reflex of *tabu was associated with the notion of death. Spirits (*?atamate) are primarily ghosts of deceased ancestors, and their presence in a cave, a rock, a stone, render the place unapproachable and dangerous. Haunted places (20) are *tabu, and so are religious ceremonies performed in the company of spirits.

According to Codrington \& Palmer (1896:196), the Mota language has a word tap 'a quiet day, for death or by order of tamate [secret societies]: no drumming, singing, playing':

(36) *tabu > MEANING 16 "a day of mourning, when villagers refrain from cheerful activities": Mota tap.

The word is here associated with death, while keeping a notion of constraint or restriction (itself reminiscent of meaning 4 'ban, proscription').

Many languages of Vanuatu now use *tabu as a noun meaning 'graveyard, cemetery':

*tabu > MEANING 17 "[N] graveyard, cemetery": Mwotlap ne-teq;

Sakao e-tev 'burial ground'; Vao tabu 'cemetery, place of burial';

Uripiv $d u b b$ 'cemetery, grave'.

Reflexes of *tabu sometimes refer to an individual grave:

*tabu > MEANING 18 "[N] grave; tomb”: Sakao e-tev 'grave';

Tamabo tambu 'grave'; Araki rapu-na 'his/her grave'; Nasarian

na-tambara, Lendamboi a-tambara 'tomb, funerary shelter'.

Many languages of Vanuatu (notably those of Santo and Malekula) preserve the etymon *tabu only with this funeral meaning 'grave, graveyard', having lost it everywhere else.

4. THE SEMANTIC SPACE OF *TABU. The previous sections have presented a vast array of meanings associated with modern reflexes of *tabu in various languages of Vanuatu. While I initially focused my attention on the languages of the Torres \& Banks islands for which I had firsthand data, I also included data from the rest of the archipelago - enough to observe some tendencies. Several meanings are widespread across the archipelago, while others appear to be specific to a certain area or an individual language. The present section will summarize our findings.

4.1 A CROSS-LINGUISTIC SEMANTIC MAP FOR *TABU WORDS. Rather than provide a linear list of meanings, it would be preferable to present our observations in an organized fashion, so as to highlight the complex organisation of the *tabu lexical domain. In the last decades, many studies have shown the value of semantic maps in order to visually represent complex 
polysemies (e.g. Pawley 2005; J. François 2007, 2013; François 2008, f/c; Georgakopoulos et al. 2016).

In line with those studies, I propose to collect all the meanings we've observed of *tabu so far, into a single semantic map. This yields Figure 3, the "semantic map of *tabu in Vanuatu".

\section{FIGURE 3 - A CROSS-LINGUISTIC SEMANTIC MAP OF *TABU REFLEXES IN VANUATU LANGUAGES}

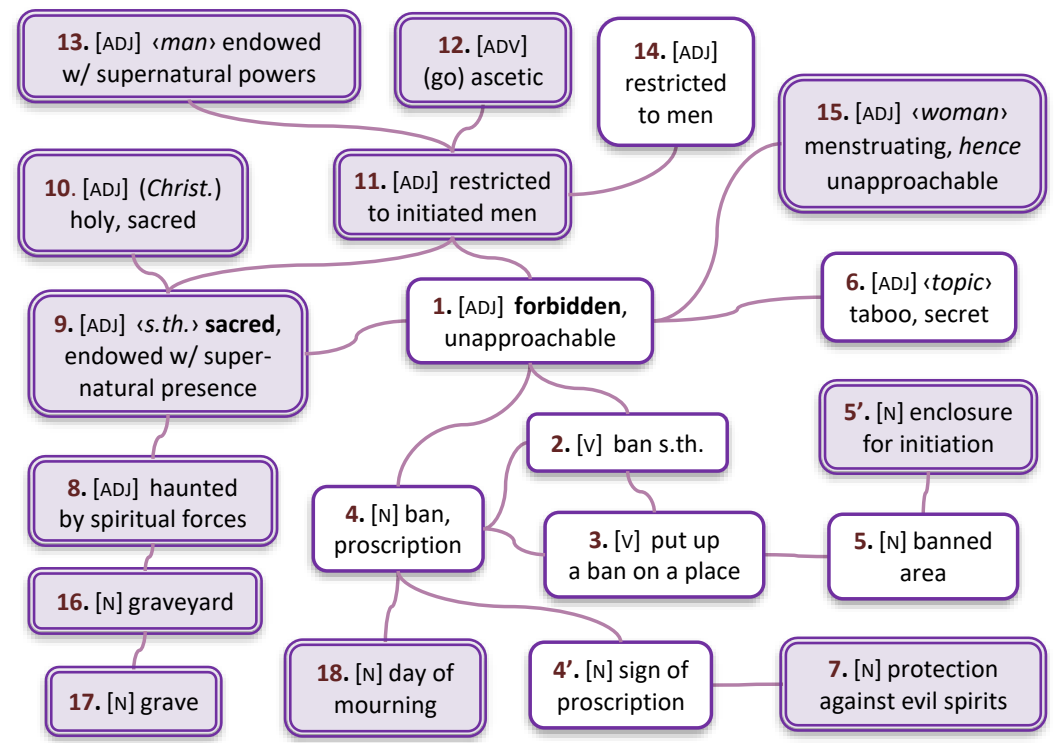

Each sense is here numbered according to its identifier in previous sections (For example, the sense 'ascetic', listed under (27) above, was there identified as "MEANING 12".). The grayed boxes with thicker contour indicate those senses which refer to spirits or to supernatural forces, either directly (e.g. \#8 'haunted by spiritual forces') or indirectly (e.g. \#12 'ascetic', \#17 'grave', etc.). Each individual sense is associated with a specific word class (Noun, Adjective, Verb, Adverb).

Contrary to what a one-dimensional list of meanings can offer, a semantic map makes the most of the two-dimensional space to indicate visually the internal structure of a polysemy. The paths linking senses together highlight the semantic affinities between certain pairs of senses. For instance, we saw that \#3 'put up a ban on a place' was the source of two sets of derived meanings: on the one hand, \{\#3 'put up a ban' $\rightarrow$ \#5 'area affected by a ban' $\rightarrow \# 5$ ' 'enclosure for initiation' $\}$; and on the other hand, \{\#3 'put up a ban' $\rightarrow$ \#4' 'sign of proscription' $\rightarrow \# 7$ 'protection against evil spirits' $\}$. 
The paths proposed here reconstruct the most likely direction of semantic shifts, regardless whether they took place before or after the breakup of the Proto-Oceanic language. As in any polysemous network generally, the path between two senses may correspond:

- to a metonymy:

e.g. ban, proscription $\rightarrow$ sign of proscription;

- to a metaphor: e.g. sign of proscription $\rightarrow$ protection against evil spirits;

- to semantic narrowing: e.g. banned area $\rightarrow$ enclosure for initiation;

- to semantic broadening: e.g. reserved to initiated men $\rightarrow$ restricted to men, etc.

The advantage of semantic maps is to bring some form of order into what may have seemed a messy set of senses. Based on a mere list of meanings, it may seem confusing how the same word may include such senses as 'graveyard', 'menstruating', 'holy', 'restricted to men', 'day of mourning', 'ascetic'... By laying out these senses in a logical order and revealing the most likely semantic paths between them, a map helps reconstruct the internal organisation of a semantic domain.

Just like any lexicographic work, these proposed connections are based on the linguist's interpretation, and may sometimes be open to debate. For example, one might have proposed that \#16 'graveyard' should really be connected to \#5 'banned area'; however, during my immersion in the Banks and Torres, I personally never encountered the notion that people were formally denied access to cemeteries, in the sense of a profane "no entry" sort of ban. Conversely, expressions such as (20) 'haunted places', usually uttered with an expression of fear, explain why I would rather see graveyards (and, by extension, graves), connected to the sense \#8 'haunted by spiritual forces'. That is, I propose to link the graveyard sense to the religious section of the map ('sacred, endowed with supernatural presence') rather than with the profane one ('forbidden, affected by a social proscription'). A corollary of this empirical method is that other researchers, based on different ethnographic observations, may wish to propose different connections between senses, resulting in welcome revisions to our semantic map.

Another way in which such a map can still be improved, would be by bringing in more data from as-yet undocumented languages; in case more senses of *tabu words are discovered, they could be added to the map, in appropriate locations. For example, Duhamel (2021), citing a previous version of my map of *tabu, proposed to add sense \#15 ('〈woman〉 menstruating, hence unapproachable'); I have here revised my map accordingly. 


\subsection{FROM THE AREAL SEMANTIC MAP TO INDIVIDUAL LEXEMIC} MAPS. Semantic maps provide an overview of a whole lexical field, while at the same time tracking with precision the various senses and their distribution across languages.

Figure 3 above does not represent the facts of a single language, but aggregates the semantic extensions of *tabu as they are found in a whole region. We can then use this "areal" map as a background, and project onto it the semantic range of each modern reflex of *tabu. The areal map then functions as an "etic grid", from where the precise contour of each emic word can be outlined (cf. Haspelmath 2003, François 2008, Evans 2010:509). I will call lexemic map the resulting chart - showing the semantic outline of one individual lexeme in a particular language.

Some languages assign to their *tabu word just one or two of the meanings on the areal map. Thus, Tamabo tambu has only kept meaning \#17 'grave', and lost all other meanings. Mwerlap uses the noun no-tom only for senses \#4 and \#7 'protection against evil spirits'; and so on and so forth.

Mwotlap also has only one direct reflex of *tabu, namely ne-teq 'graveyard' [\#16]; yet in addition, it also reflects the causative protoform *tabúa, either as a verb tōqo, 'put a ban' [\#3] or as a noun na-tq⿳亠丷厂 'ban; sign of proscription' [\#4']. All in all, reflexes of *tabu and its derivatives in Mwotlap cover a rather small portion of the map: see the lexemic map in Figure 4. (Direct reflexes of *tabu are shown with a full line; derivatives with a dotted line.)

By contrast, Figure 5 displays the array of senses associated with modern reflexes of *tabu in Hiw. Evidently, Hiw toq /tokw/ occupies a much larger portion of the semantic space than reflexes of *tabu in Mwotlap, since it includes basically all the adjectival meanings of the maximal map [\#1, 6, 8, 9, $10,11,12,13,14]$. The dotted line recalls that sense \#12 'ascetic' is rendered by a derivative form, namely the reduplication teqtoq. Finally, we can add the noun teq $\ddot{o} / \mathrm{t}^{\mathrm{w}} \mathrm{\theta} /\left[\mathrm{H} 5^{\prime}\right]$ 'enclosure for initiation', from *tabua.

A comparison of Figures 4 and 5 makes it clear that modern languages of Vanuatu with reflexes of POc *tabu assign them to different sections of the map. The contrast between Mwotlap and Hiw is all the more spectacular, that the two languages are geographically close to each other in northern Vanuatu. And yet, their reflexes of *tabu have clearly become "faux amis": two cognate forms with very different semantics. The relevant dictionary entries for Mwotlap and for Hiw, proposed in the Appendix [\$7.1], constitute one possible way to compare the lexical domains of these two languages; but the comparison of two lexemic maps, in a way, highlights similarities and differences even more clearly.

We will come back to these maps in the final discussion about diachronic change [Section 6]. 


\section{FIGURE 4 - LEXEMIC MAP OF *TABU REFLEXES IN MODERN MWOTLAP (BANKS ISLANDS).}

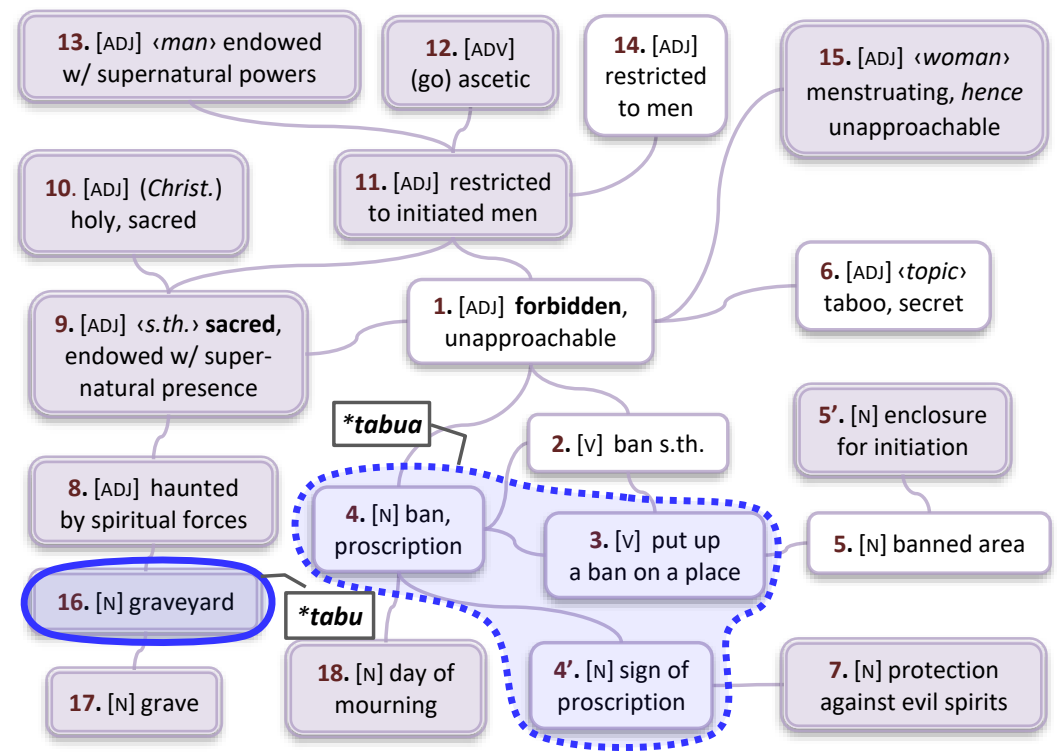

\section{FIGURE 5 - LEXEMIC MAP OF *TABU REFLEXES IN MODERN HIW (TORRES ISLANDS).}

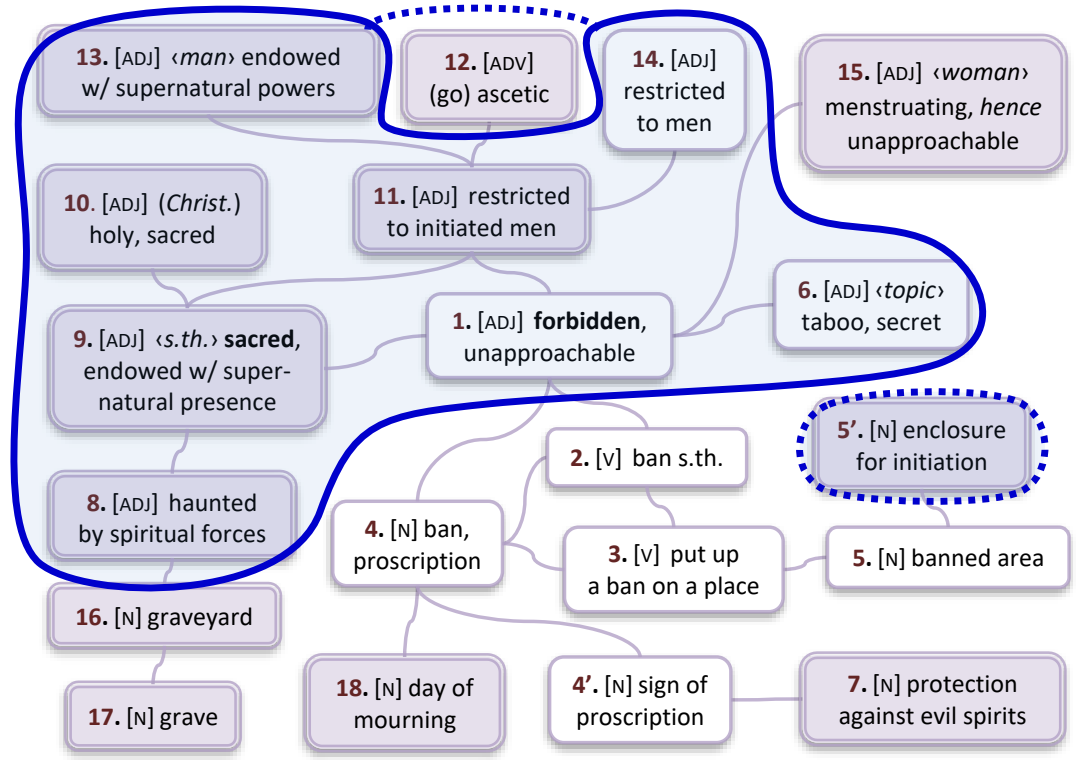




\subsection{WHEN *TABU WORDS UNDERGO LEXICAL REPLACEMENT.}

Among the maximal array of meanings associated with *tabu, each lexemic map highlights those which have been preserved by a given language, to this day. Among the various questions raised by such maps, one would be the following: How do these languages treat the portions of the map that they don't lexify with *tabu? Are there other roots that are semantically close to *tabu, and which have come to fill the gaps? What are the semantic contrasts in those cases? Due to space limitations, and the sheer number of languages involved, this discussion must remain short, but a few examples can already be discussed.

When a language does not use *tabu for one of the senses of Figure 3, this may correspond to two cases: either it doesn't express it at all; or it encodes it using a different word.

The first possibility is that a given sense in Figure 3 is simply not lexified at all in the target language. While that situation is rare in the case of basic vocabulary, it is not that uncommon when the referents are themselves highly sensitive to local cultural practices. Thus, all languages of Vanuatu (and elsewhere) can be assumed to have a word for 'grave' or 'graveyard' - insofar as people bury their dead in a dedicated area. But we can't take it for granted that all cultures in Vanuatu, in all their cultural diversity, should share the practice of putting up a "leaf to protect a newborn child from evil spirits" [\$3.1.4]; of building a "special enclosure in the bush for initiation rituals" [\$3.2.2]; or of "going ascetic with respect to seafood and sexual intercourse, as a token of self-restraint" [\$3.2.4]. Just as many of those concepts are absent from European languages, likewise they can be lacking from some Vanuatu societies which happen not to share a particular custom.

The second, perhaps more common case, is when a given sense is indeed lexified by a modern language, but with a root other than *tabu. For example, in Erromango, the language Sye has a polysemous word nempacu whose meanings include: "taboo, forbidden"; “'woman〉 taboo due to menstruation"; "taboo because marked with leaves" - see also nempari "protection placed at s.o. 's door to keep away evil spirits" (Crowley 2000). While these two forms (nempacu, nempari) are not related to *tabu, they have evidently come to occupy part of its semantic territory.

Likewise, Mwotlap has now lost *tabu, except for the sense 'graveyard'. As for other meanings of the domain, they are now lexified by other roots; I will here discuss two in particular: *royo and *salayoro (François 2013:230-3). ${ }^{24}$ The excerpts from the Mwotlap dictionary shown in the Appendix [\$7.1] include not only the reflexes of *tabu (teq 'cemetery', tōqō 'put up a ban'...) mentioned earlier, but also two lexemes that have now entered the domain: yon 'quiet; holy, sacred' and halgoy 'secret, taboo' - respectively the modern reflexes of *rono and *salayoro.

${ }^{24}$ The reconstructions are given here at the level of PTB, "Proto Torres-Banks". 


\section{FIGURE 6 - LEXEMIC MAP SHOWING SOME OF THE ROOTS USED BY MODERN MWOTLAP TO LEXIFY THE MAXIMAL SEMANTIC DOMAIN OF *TABU.}

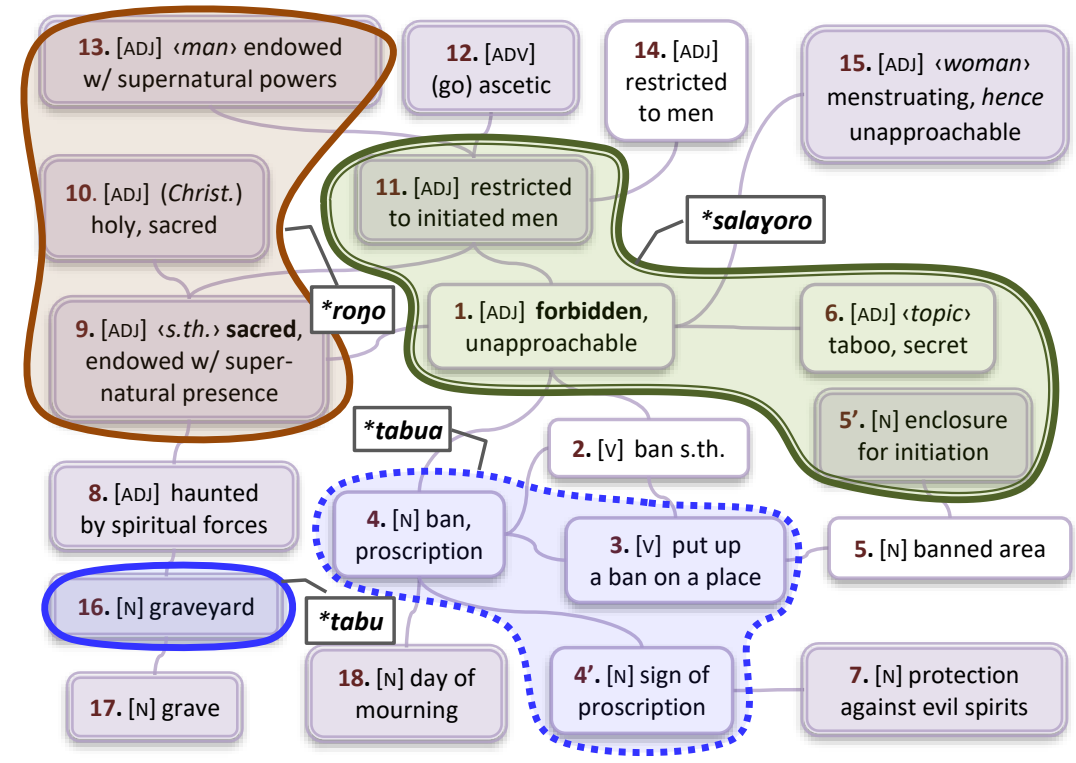

Each of these two words covers a certain section of the maximal map of *tabu. First, the adjective yon /joy/ ( $<$ *rono), whose original meaning was probably 'quiet, silent', is used for senses \#8 'endowed with spiritual forces', as well as for its Christian counterpart \#9 'holy, sacred'. This adjective yon focuses on the inherent sanctity of an object or place, and does not specifically entail the notion of proscription or taboo. This is consistent with the definition given for its cognate roño in Mota, which Codrington \& Palmer (1896:146) gloss: "sacred, unapproachable, with inherent sanctity: not tapu". On the other hand, the word halgoy (<*sala-yoro, etymologically 'closed path') evokes the notion of secret, taboo, proscription [\#1, \#6], particularly in relation to the secret knowledge of initiates [\#11]. As a noun, halgoy also refers to the secret enclosure devoted to initiation rituals [ $\left.\# 5^{\prime}\right]$.

Interestingly, the contrast between *royo and *salayoro is here reminiscent of the opposition drawn by Benveniste [\$3.2.1] between, respectively, positive holiness ("what is charged with divine presence", *royo) - and negative sanctity ("what is forbidden for men to contact", *salayoro), except the latter should be redefined as "what is forbidden to non-initiates". In other terms, while the two types of sanctity are colexified in Hiw toq $(<*$ tabu), they are dislexified (i.e. lexically distinct, cf. François f/c) in modern Mwotlap, through the contrast between * royo and *salayoro. The semantic domain of sacredness, which was originally unified under *tabu, historically underwent a lexical split 
in Mwotlap (François f/c), resulting in a contrast between two forms of sanctity - one positive, one negative.

Figure 6, derived from Figure 4 above, shows how modern Mwotlap now divides up the maximal semantic domain of *tabu across several lexical items; these include reflexes of *tabu, *tabua, *royo and *salayoro. Other senses are either not expressed in Mwotlap, or they are lexified with other roots again.

In a similar spirit, Duhamel (2021:28) has shown how the Raga language of Pentecost has split the lexical field of *tabu across two overlapping polysemies. On the one hand, the word sabuga, which she considers a reflex of *tabu, has kept most spiritual meanings, and can be glossed 'sacredness based on powers relating to non-human beings'. On the other hand, a word gogona now occupies a large portion of the map, and is glossed 'sacredness based on powers relating to human beings'. Duhamel's study also shows the efficacy of semantic maps when describing complex and evolving polysemies.

Given enough fine-grained data, similar lexemic maps could be drawn for the various languages of Vanuatu, each displaying a different organisation of this particular domain. Such maps would illustrate how the root *tabu has conceded portions of its semantic territory to other etyma, different in each language.

\section{FROM MODERN LANGUAGES TO PROTO OCEANIC, AND BACK}

5.1 A NOTE ON METHODOLOGY. Finally, what can be said about the reconstruction of earlier linguistic stages? The reasoning so far has been resting on synchronic data from modern languages; and the maximal semantic map of *tabu (Figure 3) was created by compiling together the principal meanings encountered in that synchronic exploration.

One hasty interpretation would be to take that maximal map as representing the whole semantic array of the root *tabu in Proto Oceanic times: if such were the case, then this etymon would have been initially hyperpolysemous, and the process leading to modern times would have mostly consisted in each language losing some of these senses. But there is no reason for assuming such a scenario. After all, some of the meanings listed above (e.g. [\#12] 'go ascetic', [\#18] 'day of mourning'...) were only attested in a handful of languages, and were most probably local innovations, that took place by extending or reshaping earlier meanings.

Ideally, when reconstructing the semantic contour of a given etymon, we should impose upon ourselves the same sort of rigor and demands as we do for computing its phonetic form. And indeed, while the Comparative method has more often concerned itself with the discussion of sound change, there is no reason why its principles could not be extended to semantic reconstruction (cf. Blust 1987, Pawley 2005).

One relevant principle, sometimes known as Meillet's principle, concerns the conditions for a given feature to be reconstructed at the level of a family's 
ancestor - while avoiding the pitfalls of contact or coincidence. Meillet (1903), working on Indo-European, proposed that an etymon should be reconstructed in a protolanguage if, and only if, it is attested in at least three distinct subgroups descended from it (cf. Rankin 2003:191).

In line with other authors, I propose to apply Meillet's principle to the semantic domain. In a lexical family of cognate words all descended from the same etymon, a given sense should be assigned to the protoform if, and only if, it is attested in at least three subgroups. Even though we still lack relevant data for many Oceanic modern languages, a fair sample can be found in Robert Blust's Austronesian Comparative Dictionary, under the entry *tambu (Blust \& Trussel 2021). I propose to compare the glosses provided by Blust for Oceanic languages with the 18 senses I already identified for Vanuatu languages [Figure 3 p.24].

5.2 REFLEXES OF *TABU OUTSIDE VANUATU. Among all the meanings of *tabu that were attested in Vanuatu (numbered \#1-18 on Figure 3), the list below shows which ones are attested in Oceanic subgroups outside Vanuatu. Each subgroup is represented by one language. I indicate in bold those senses of the map that are also found in at least two Oceanic subgroups besides Vanuatu. A meaning followed by a star $(*)$ is apparently attested only in Vanuatu [\#6-7, 13-18], at least based on my documentation.

In some cases marked by curly braces (e.g. under [\#5] below), the semantic match is not perfect, but the meanings are close enough to warrant a mention. A ' ++ ' sign means there are many other senses or examples, of which only a small sample is cited here.

\section{1 - [adj] forbidden, unapproachable}

$\rightarrow$ Bugotu [Southeast Solomonic] $t a b u$ 'sacred, forbidden; a prohibition placed on use or handling of anything';

$\rightarrow$ Wayan [Central Pacific] tabu 'be forbidden, prohibited by strong communal sanction; (place, thing) be prohibited from use' ++

$2-[\mathrm{v}] \quad$ prohibit, set apart

$\rightarrow$ Gela [Southeast Solomonic] tambu 'set apart'++

$\rightarrow$ Gilbertese [Micronesian] tabu- $a$ 'to forbid, prohibit, interdict'

$3-[\mathrm{v}] \quad$ put up a ban on a place

$\rightarrow$ Fijian [Central Pacific] tabu 'forbidden, prohibited, implying a religious sanction, but now used also for legal prohibition, such as "no admission"”;

$\rightarrow$ Māori [Polynesian] tâpu-i 'mark to indicate claim or right to property'

$4-[\mathrm{n}] \quad$ sign of proscription

$\rightarrow$ Bugotu [SES] $t a b u$ 'a prohibition placed on use or handling of anything'

$\rightarrow$ Woleaian [Micronesian] tab 'ban, ritual restriction protected by supernatural sanction, marked by a taboo sign'

$\rightarrow$ cf. Biak [shwng] kābus 'tree branch or anything else placed on fruit tree or other object by its owner in order to make others afraid to approach the 
marked object lest ill fortune befall them'

5 - [n] enclosure for initiation rituals

$\{\rightarrow$ Kwaio [SES] $a b u$ - $a b u$ 'sacred area beside men's house where ancestral spirits are addressed';

$\rightarrow$ Mandegusu [WOc] tabu-na 'shrine, skull-house, sacred or forbidden place'\}

6 - [adj] (topic) taboo, secret*

$7-[\mathrm{n}] \quad$ protection against evil spirits*

8 - [adj] haunted by spiritual forces

$\rightarrow$ Māori [Polyn.] tapu 'under religious or superstitious restriction';

$\rightarrow$ Tanga [Western Oceanic] tabun 'ritually restricted (used in reference to the immediate environs of a funeral house of a certain clan - only members of that clan may walk on this ground)'

9 - [adj] holy, sacred

$\rightarrow$ Cheke Holo [WOc] tabu 'taboo, prohibited, sacred'

$\rightarrow$ Bugotu [SES] tabu 'sacred, holy'

$\rightarrow$ Rennellese [Polyn.] tapu 'taboo, forbidden, sacred, hallowed'

10 - [adj] holy, in a Christian sense*

11 - [adj] restricted to initiated men

$\rightarrow$ Niue [Polynesian] tapu 'prohibited to common people'

$\rightarrow$ Gilbertese [Micronesian] $t a b u$ 'forbidden, prohibited (generally used with religious meaning of sacred, consecrated)'

$12-[v]$ be ascetic, observant of rituals

$\rightarrow$ Roviana [Meso-Melanesian] tabu 'put a taboo on food';

$\rightarrow$ Molima [Papuan Tip] tabu-gu 'a food forbidden to me'

$\rightarrow$ Rennellese [Polyn.] tapu 'to observe taboos, as on the Sabbath'

13 - [adj]〈man〉 endowed w/ supernatural powers*

14 - [adj] restricted to men*

15 - [adj]〈woman〉 menstruating, hence unapproachable*

$16-[\mathrm{n}]$ graveyard*

$17-[\mathrm{n}] \quad$ grave*

$18-[\mathrm{n}]$ day of mourning*

Finally, the evidence points to one meaning that is not found much in Vanuatu, yet is attested in at least three Oceanic groups. This is the general prohibitive 'don't [do that]!', a modal marker referring to any action [\$2.2]:

19 - [mod] general prohibitive: don't!

$\rightarrow$ Nauna [Admiralties] tapu 'dehortative, don't'

$\rightarrow$ Tubetube [WOc] $t a b u$ 'don't'

$\rightarrow$ 'Āre'āre [SES] apu 'prohibitive, dehortative to children'; Arosi $a b u$ 'don't'.

This meaning will become sense \#19 in our semantic map of Proto Oceanic. 
5.3 THE MEANINGS OF *TABU IN PROTO OCEANIC. If we follow strictly Meillet's principle, we should reconstruct for Proto Oceanic only those senses that are attested in at least three subgroups of Oceanic. The result of our reconstruction is synthesized in the form of a lexemic map [Figure 7], showing the most likely semantic array that can be reconstructed for POc *tabu. My hypothesis is that *tabu in Proto Oceanic only had the meanings shown inside the thick line; the senses shown outside of that line are later semantic extensions local to Vanuatu [\$6].

\section{FIGURE 7 - LEXEMIC MAP SHOWING THE MOST LIKELY SEMANTIC RECONSTRUCTION FOR THE PROTO-OCEANIC ETYMON *TABU.}

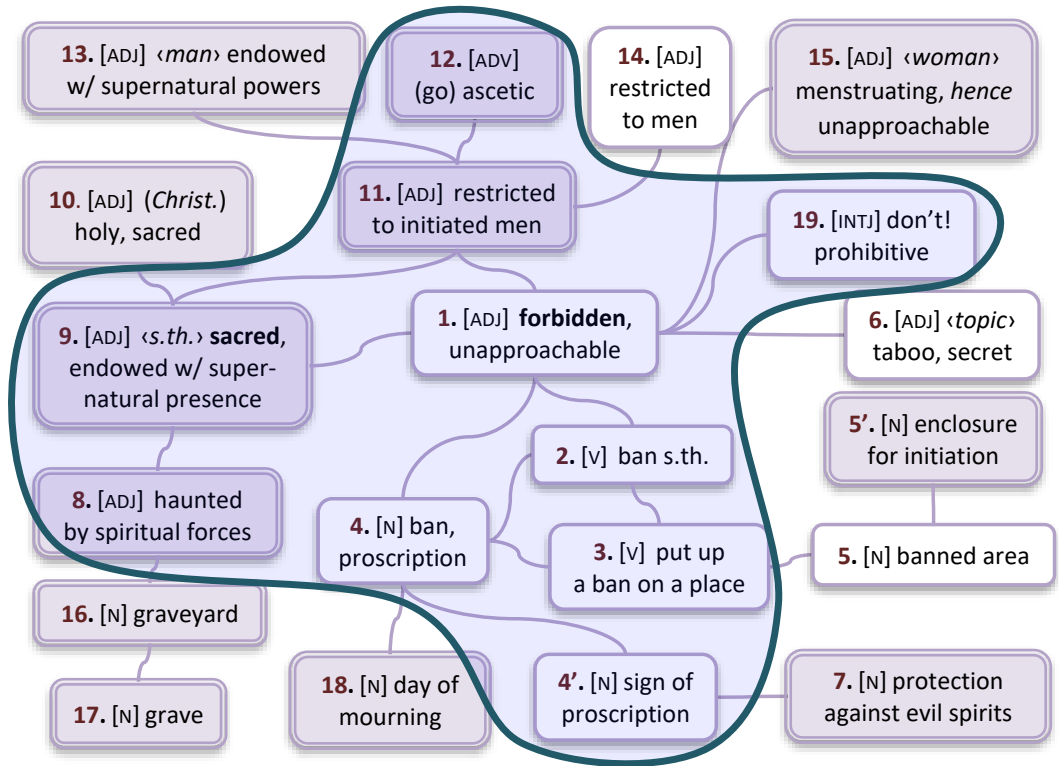

In sum, the protoform *tabu of Proto Oceanic can be reconstructed with two sets of meanings, both of which revolve around the notion 'forbidden, unapproachable'. Some of these senses refer to profane, social practices of proscription, such as banning entrance to a territory, or uttering a regular prohibition ('don't!'). Other senses relate to the inherent sacredness of a place or object that is endowed with a divine or supernatural presence - whether that presence induces fear or a sense of awe: POc *tabu evidently colexified positive and negative sanctity. Somewhat lying in between these two poles, profane and sacred, are the senses linked to funeral practices or initiation rituals - when spirits and humans meet.

We now have the answer to the initial puzzle formulated at the very beginning of this study [Section 1]. Even though the anthropological literature has always focused solely on Polynesian languages when discussing the 
religious implications of their word tapu, the evidence collected from other Oceanic languages makes it clear that the religious meanings of *tabu, implying sacredness and reverence towards supernatural forces, were present already in Proto-Oceanic times.

If POc *tabu had to be summarized in a short gloss, I would propose (39):

POc *tabu "off limits, forbidden; sacred, due to a sentiment of awe and fear before spiritual forces"

This gloss attempts to capture both the mundane senses ('ban an area'...) and the religious ones, which are evidently prominent in the semantic makeup of *tabu. While a brief gloss such as (39) may be convenient in certain contexts, nothing beats a full lexical map in terms of semantic coverage and precision.

\section{CONCLUSION: THE TECTONICS OF SEMANTIC CHANGE.}

The present study illustrated the sort of semantic reconfigurations that characterize semantic change over time. A given meaning, which used to be lexified (encoded) by a certain word $\mathrm{X}$ at a given point in time, will end up being expressed by a different word several centuries later, following events of semantic shift and lexical replacement. As a corollary, a given lexeme can show quite different semantic contours on a map at distinct points of its historical development (see also J. François 2007, 2013; Georgakopoulos \& Polis $\mathrm{f} / \mathrm{c}$ ).

This slow process of constant semantic reshaping, which I have elsewhere dubbed "lexical tectonics" (François f/c), can fruitfully be represented using semantic maps. Through their spatialized layout, maps are an effective tool for representing the paths followed by words as they evolve through semantic space, expanding or restricting their meaning, shifting from one sense to the other, shoving around other words as they push into new semantic territory. As the lexemic outlines of words (represented by the blobs on our maps) change their shapes over time, they emulate tectonic plates shifting, drifting in space, and colliding with each other.

Now that we have reconstructed the semantic contour of POc *tabu, we may take it as our new starting point for assessing the semantic history of this etymon and its reflexes. If we compare the shape of POc *tabu (Figure 7) with modern Hiw (Figure 5), we find that the Hiw word toq is semantically rather conservative: this reflex of *tabu has kept such core meanings as 'forbidden' or 'sacred', and has preserved strong ties with spiritual powers. Conversely, Hiw has receded some territory with respect to the profane meanings of *tabu (e.g. 'ban entrance to a place'); and it has expanded on the religious side, resulting in such semantic extensions as 'ritual enclosure' or '(person) endowed with supernatural powers'.

Mwotlap has followed a very different evolution. Following a cascade of semantic changes - including lexical splits, mergers, and shifts (François f/c) the root *tabu has ended up confined to a single sense \#16 'graveyard'. While 
this meaning does not seem to reconstruct to POc, it constitutes (together with \#17 'grave') an innovation found in many languages of Vanuatu [\$3.3]. As for the other meanings initially connected to *tabu, they have been relexified using different roots: *royo 'silent $\rightarrow$ holy', and *salayoro 'closed path $\rightarrow$ secret, prohibited' [Figure 6]. This process of lexical replacement must have taken several steps. Initially, \#16 'graveyard' \#17 'grave' must have arisen as a semantic extension of \#8 'place haunted by spiritual forces', at a time when that sense was still expressed by *tabu. Later on, that meaning \#8 underwent competition between *tabu and an intruder etymon *rono (originally 'quiet'). After a period of lexical rivalry between *tabu and *royo (a struggle still ongoing today in Mota - see $\$ 4.3$ ), eventually * rono prevailed in Mwotlap for meanings \#8 and \#9 'haunted, sacred, holy'. Whether it resolves or not eventually, this sort of competition between two words for a given meaning - a type of lexical variation - is the key to any change in the lexicon (Sweetser 1990:9; Evans \& Wilkins 2010; François f/c).

Parallel with the territorial shrinking of the root *tabu, Mwotlap witnessed the territorial expansion for *salayoro 'forbidden path' $\rightarrow$ 'secret' $\rightarrow$ 'taboo'; as a result, *tabu was eliminated from meanings $\# 1,5$, 6, 11. All in all, Mwotlap has lost *tabu everywhere - except for one pocket of retention, as it were, around the innovative meaning \#16 'graveyard'. In spite of their genealogical relatedness and geographical proximity, the languages Hiw and Mwotlap now differ quite drastically in their patterns of lexification - that is, in the way they cut up the semantic space, and distribute word forms across a network of senses.

Such examples are precious for the insights they give us on the history of linguistic change, not just in this region, but also in more general terms of diachronic lexicology.

\section{APPENDICES}

7.1 DICTIONARY ENTRIES. This appendix contains a sample of lexical entries that have been cited in this chapter, as they appear in the dictionary of Mwotlap (François 2020a), and in a future dictionary of Hiw.

\subsubsection{Mwotlap}

teq (ne-teq) $\left[\mathrm{n} \varepsilon t \varepsilon k \widehat{p}^{\mathrm{w}}\right] \mathrm{N}$ graveyard, cemetery. $\triangleright$ Ige talmiy kēy so van a le-teq. The shaman's soul travels to the cemetery. $\triangleright$ Nēk so van ⿳亠丷⿵冂⿱八口𧘇 a le-teq? (joc.) Do you want to go already to the cemetery? See nu-quy (tamat) 'grave'.

[POC *tabu 'forbidden; sacred]

$\mathbf{t}[\overline{\mathbf{o}}] \mathbf{q} \overline{\mathbf{o}}\left[\mathrm{trk}^{\mathrm{k}} \overline{\mathrm{p}}^{\mathrm{w}} \mathrm{v}\right] \mathrm{vT}$ put up a sign of ban onto o.'s property, so as to prevent aliens from entering it. $\triangleright$ No mal tōq⿳亠口冋 mahē gōh kē, n-et tit kal bat vēh te; ba so iyē ma-van me gōh? I had put up a ban on this place, so nobody would enter; so who can be coming this way? Syn. ak goy.

na-tq $\overline{\mathbf{0}}\left[\right.$ natkp $\left.^{\mathrm{w}} \mathrm{v}\right] \mathrm{N}$ a ban put up on a place; public sign announcing that ban, in the form of leaves bundled

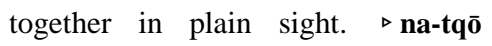


b-ēmyoñ [ban for the church] fishing zone reserved for the preparation of the church day.

[РТВ *tab ${ }^{w}$ ua $;$ cf. Mota tapua 'a thing or place made taboo; a mark or sign set up'; $P O c$ *tabu 'forbidden; sacred']

halgoy (na-halgoy) [halyoj] $\mathrm{N}$

(1) a secret. $\triangleright$ Et-halgoy vitwag te. $I t^{\prime} s$ not a secret. $\triangleright$ Ige lōqōvēn kēy nē-dēmap a nē-dēmap, veg na-halgoy non ige tā̄an, so ni-tiy tamat nan aē. Women pay [this ritual] the greatest respect, because it's a secret of the men, which is tied to spirits. Syn. lehigoy. See bat 'secret (adj.)'.

(2) (rare) (body) taboo parts, privates. $\triangleright$ Tenenen a- la-tayben ige lōqōvēn en; a la-halgoy non ige lōqōvēn. That is found on the body of women, on their taboo parts.

(3) taboo, proscription. $\triangleright$ Nēk t-et vēhte kē. Veg na-halgoy ! Na-halgoy so nēk so et kē. You can't see her, it's forbidden. You don't have the right to see her.

(4) (meton) secret enclosure, strictly forbidden to non-initiates, where male candidates to initiation gather; hence secret society. \ Na-halgoy so ni-wot, a so ige tamat kēy so wot van la-halgoy. The initiation rituals are born when the spirits appear in the secret enclosure. - During a few weeks, a group of young men will settle in a secret enclosure outside the village, in the bush. Strictly reserved to men, this enclosure is called na-halgoy 'secret, taboo'. Initiates learn there important and secret knowledge from their elders, including myths, tales, dances, songs, poems, and lessons of morality. That wisdom draws its source from spirits (na-tmat), who are present in the enclosure. See lēs 'initiate'; n⿳亠̄⿵冂-sōq 'grade-taking process'. van la-halgoy $\sim \overline{\mathbf{m}} \bar{o} \mathbf{l}$ la-halgoy. $\mathrm{VI}$ lit. "go into Secret": (young boy) enter the period of initiation, by moving for a few weeks into the secret enclosure; hence follow the initiation rituals, become initiated. $\triangleright$ Nēk wo ma-van tō la-halgoy, no mas mōk geh hōw l-eh. If you went through the initiation rituals, I will mention it in my poem. $\triangleright$ Ige mey malig hōw, kēy tit-van te muy vēh te la-halgoy. Those who are underaged are not allowed to take part in secret ceremonies. $\triangleright$ Ige $\overline{\mathbf{m}} \mathbf{o} \mathbf{m} \bar{o} \mathbf{l}$ van la-halgoy a kem et-lēs tamat qete : nē-dēw mi kemem, kem nē-dēmap so kem so hayveg van. When men used to gather together in their secret societies, we the non-initiated were quite impressed, we felt too much awe to join them.

[<*sala-yoro 'forbidden path']

yon̄ [jon] ADJ (1) (anc) quiet, silent. ॰ Only in tog-yon 'keep quiet', and in the reduplicated form yoyon̄ 'silent'.

(2) (place, thing+) endowed with special status inducing awe and respect: sacred, numinous.

ne-vet yon $\mathrm{N}$ <Magic> lit. "holy stone": a stone endowed with supernatural aura or power, used for rituals of sorcery (vēgēl). $\triangleright$ Nok sese eh van le-vet yon̄ vitwag, tō kē ni-vēhgi bago. I chant to a sacred stone, so it turns into a shark.

(3) <Christ> holy, saint. $\triangleright \mathbf{n}$-ē̄̄ yō̄ [holy house] church $\triangleright \mathbf{n u}-\mathbf{V u}$ Yon the Holy Spirit $\triangleright$ vasigyon baptize.

yon̄ N (no-yon̄) numen, holiness, sacredness (of s.th., s.o.). \Nitog hahalege n-et a kē n-en hiy en, veg no-yoñ tiple su. Do not step over someone lying on the ground: this would harm her sanctity.

[cf. Mota ron̄o 'sacred, unapproachable+'] 


\subsubsection{Hiw}

toq $\left[\mathrm{t}^{\mathrm{w}}\right] \mathrm{ADJ}$ (1) (stg) endowed with special status inducing awe and special respect: sacred.

(2) <Christ> sacred, holy. \ Mama te rēene, ne ya në toq. Our father in Heaven, hallowed be Thy name.

gengon toq $\mathrm{N}$ lit. "holy food": altar bread, Lord's Supper. \ n'oye-vë-gengon-toq [the consumption of holy bread] the Eucharist

(3) (place) unapproachable, off limits, typic. due to being haunted by ghosts (temët).

nwwute toq $\mathrm{N}$ lit. "taboo place": locations on the island known to be haunted by ghosts and spirits (temët), and to which visits are advised against.

(4) (topic) taboo, not meant to be mentioned in public. $\triangleright$ Ne voygë pe nëne nëgë toq, tite tat vegevage vitikëyë ye n̄wute pe tuqun̄kë ve toge ie mi tun̄wuyegë. Subjects like that are a bit taboo: you can't just mention them randomly when kids or women are around.

(5) (s.o.) numinous; endowed with supernatural powers ( $c f$. mane). Syn. trāane.

tayö toq $\mathrm{N}$ lit. "numinous person": a man endowed with supernatural, magic powers, hence worthy of higher status in the grade-taking system

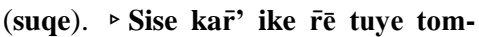
n̄wëtom ike on r̄ōw wrog, ike ne tayö toq. (ritual pedestal tuye) They'll shoot arrows at you [as you stand] on the stone pedestal; if you survive, this means you're a magic man.

(6) (s.th., place) of restricted access, due to its association with initiation rituals or grade-taking ceremonies. $\triangleright$ Tekñwa pe sise ve suqe piti, sise tan̄wöy on rak ne temët yö teqö toq. Only those who have gone through initiation are entitled to handle spirits in the sacred enclosure. Cf. teqtoq 'ascetic'.

vönyö toq $\mathrm{N}<$ Hist> lit. "sacred land": area in a village that was restricted to initiated men, and forbidden to noninitiates. $\triangleright$ Ne qor̄ ve toge takē vönyö toq. Takē vönyö toq pe takē n̄wute pe ne gemoy vē ēn eye. Stone mausoleums [for high chiefs] are erected on sacred land. We call 'sacred land' the area around the house of initiated men.

$$
\begin{gathered}
{\left[<* / \mathrm{ta}^{\mathrm{m}} \mathrm{b}^{\mathrm{w}} \mathrm{u} / ;\right.} \\
\text { POC *tabu 'forbidden; sacred'] }
\end{gathered}
$$

teqö $\left[\operatorname{tək}^{\mathrm{w}} \Theta\right] \sim$ töqö. $\mathrm{N}$ enclosure, restricted space meant to be kept off aliens.

teqö toq $\mathrm{N}$ lit. "sacred enclosure": the area, gener. hidden in the bush, where initiation rituals take place. $C f$. toq 'sacred'.

[PTB *tab ${ }^{w}$ ua; cf. Mota tapua 'a thing or place made taboo; a mark or sign set up'; $P O c$ *tabu 'forbidden; sacred']

teqtoq [tวk $\left.{ }^{\mathrm{w} t} \mathrm{k}^{\mathrm{w}}\right]$ ADV (act) in a pious or ascetic way, in adequacy with constraints associated with initiation rituals.

vën teqtoq $\mathrm{VI}$ lit. "go ascetic": (man) enter a period of ritual restrictions on food and sexual relations, during the process of initiation. $\triangleright$ Sise vën teqtoq, sise veyvoy: sise tat gon ne pēgone; sise tat vën yeqyōq mi tun̄wuyegë. Ike mas yöy teqtoq voy-kön voy-köñ voy-köñ. As [initiates] become ascetic, they must enter a mode of avoidance. They aren't allowed to eat anything from the sea; and they cannot go around with women. You must live piously like that, every single day. Syn. veyvoy.

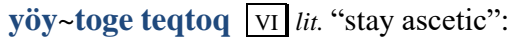
(man) be ascetic during a given period. 
7.2 LIST OF LANGUAGES AND SOURCES. This table lists the languages discussed in this study [see Map 1]. Glottocodes refer to the open-access database of languages glottolog.org (Hammarström et al. 2021). For each language, I provide the reflex of *tabu, transcribed in IPA; for meanings, see Section 3.

\begin{tabular}{|c|c|c|c|}
\hline Language & *tabu reflex (IPA) & Glottocode & \\
\hline ANEJOM & itap $^{w}$ & anei1239 & Lynch \& Tepahae 2001 \\
\hline ARAKI & rapu & arak1252 & François $2002+$ pers. data \\
\hline DORIG & ta:mb & weta1242 & François $2013+$ pers. data \\
\hline Hiw & $\mathrm{t}^{\mathrm{w}} ; \operatorname{tok}^{\mathrm{w}} \boldsymbol{\theta}$ & hiww1237 & François 2013, 2021a, pers. data \\
\hline KIAI & tapu & fort1240 & Clark $2009: 187$ \\
\hline KORO & teâm & koro1318 & François 2013 + pers. data \\
\hline LEHALI & tpu & leha1243 & François 2013 + pers. data \\
\hline LENDAMBOI & a-tambərə & lete1242 & Charpentier 1982: 2.1 .7 \\
\hline Lo-ToGA & tok ${ }^{\mathrm{w}} ;$ tək $^{\mathrm{w}} \partial$ & loto1240 & François 2013 + pers. data \\
\hline MoTA & tap & mota1237 & Codrington \& Palmer 1896 \\
\hline MWERLAP & tom; no-tom & merl1237 & Durand 2014 \\
\hline MWOTLAP & $\mathrm{n} \varepsilon-\mathrm{t} \varepsilon \mathrm{k} \widehat{\mathrm{p}^{\mathrm{w}}} ; \mathrm{t} \sigma \mathrm{k} \widehat{\mathrm{p}}^{\mathrm{w}} \mathrm{T}$ & $\operatorname{mot} 11237$ & François 2013,2020 , pers. data \\
\hline NAFSAN & tap & sout 2856 & Thieberger 2011 \\
\hline NAMAKIR & ${ }^{\mathrm{n}} \mathrm{dam}$ & nama1268 & Clark $2009: 187$ \\
\hline NASARIAN & na-tambərə & nasa1240 & Charpentier 1982: 2.1 .7 \\
\hline NESE & $\mathrm{sa}^{\mathrm{m}}$ bur & nese1235 & Crowley 2006a \\
\hline NGUNA & tapu & ngun1274 & Clark $2009: 187$ \\
\hline NOKUKU & toptop & noku1237 & Clark 2009 : 187 \\
\hline RAGA & sambuya $^{\mathrm{m}}$ & hano1246 & Duhamel 2021 \\
\hline SAKAO & $\varepsilon t \varepsilon \beta$ & saka1289 & Clark $2009: 187$ \\
\hline SYE & itvor, tompor & siee1239 & Crowley 2000 \\
\hline ТАМАВО & $\mathrm{ta}^{\mathrm{m}} \mathrm{bu}$ & malo1243 & Clark $2009: 187$ \\
\hline TEANU & etapu & tean1237 & François 2021a, 2021b \\
\hline URIPIV & ${ }^{\mathrm{n}} \mathrm{du}^{\mathrm{m}} \mathrm{B}$ & urip1240 & Lynch 2020 \\
\hline VAO & $\mathrm{ta}^{\mathrm{m}} \mathrm{bu}$ & vaoo1237 & Clark $2009: 187$ \\
\hline VERA'A & $\mathrm{Pu}^{\mathrm{m}} \mathrm{bu}(\mho)$ & vera1241 & François $2021 \mathrm{a}+$ pers. data \\
\hline
\end{tabular}

To these language names, one can add:

- PCEMP = "Proto Central Eastern Malayo-Polynesian"

- $\mathrm{PNCV}=$ "Proto North Central Vanuatu"

- $\mathrm{PTB}=$ "Proto Torres-Banks".

Unless otherwise specified, data concerning Oceanic or Austronesian languages outside Vanuatu are cited from Blust \& Trussel (2021). 
7.3 GLOSSES. Glosses follow the Leipzig glossing rules. Additional glosses include the following.

$\begin{array}{llll}\text { ANA } & \text { Anaphoric } & \text { OBL } & \text { oblique } \\ \text { ART } & \text { noun article } & \text { ORIG } & \text { originative } \\ \text { BKG } & \text { Background aspect } & \text { POT } & \text { Potential } \\ \text { CPLT } & \text { Complete aspect } & \text { PROH } & \text { prohibitive } \\ \text { HUM } & \text { gender classifier for humans } & \text { POT } & \text { potential } \\ \text { IPFV } & \text { Imperfective } & \text { QUOT } & \text { quotative } \\ \text { IRR } & \text { Irrealis } & \text { REL } & \text { relativizer } \\ \text { LOC } & \text { Locative } & \text { STAT } & \text { stative aspect } \\ \text { NPL } & \text { non-plural } & \text { SBJV } & \text { subjunctive }\end{array}$

\section{REFERENCES}

Ahnne, Edouard. 1994 [1917]. De la coutume du Pi'i et des modifications qu'elle apporta au vocabulaire tahitien. Bulletin de la Société des études océaniennes 261-62: 14-17.

Allan, Keith \& Kate Burridge. 2006. Forbidden words: Taboo and the censoring of language. Cambridge: Cambridge University Press.

Bender, Andrea \& Sieghard Beller. 2003. Polynesian tapu in the 'deontic square': A cognitive concept, its linguistic expression and cultural context. Proceedings of the Annual Meeting of the Cognitive Science Society 25.

Benveniste, Émile. 1973. Indo-European Language and Society. Miami linguistics series, 12. Miami: University of Miami Press.

Blust, Robert. 1978. Eastern Malayo-Polynesian: a subgrouping argument. In Stephen A. Wurm \& Lois Carrington (eds.), Second International Conference on Austronesian Linguistics: Proceedings. Fascicle 1, 181-234. Canberra: Australian National University.

. 1980. Austronesian etymologies. Oceanic Linguistics 19 (1/2). 1-189.

- 1981. Linguistic evidence for some early Austronesian taboos. American Anthropologist 83(2). 285-319.

- 1987. Lexical reconstruction and semantic reconstruction: The case of Austronesian "house" words. Diachronica 4 (1-2). 79-106.

Blust, Robert \& Stephen Trussel. 2021. Entry 'tambu'. Austronesian Comparative Dictionary, online edition. [http://www.trussel2.com/acd/acd-s_t.htm\#30099, accessed 2 June 2021].

Clark, Ross. 2009. *Leo Tuai: A comparative lexical study of North and Central Vanuatu languages. (Pacific Linguistics, 603.) Canberra: Australian National University.

Codrington, Robert H. 1891. The Melanesians: Studies in their anthropology and folklore. Oxford: Clarendon Press.

Codrington, Robert H. \& John Palmer. 1896. A dictionary of the language of Mota, Sugarloaf Island, Banks Islands. London: Society for Promoting Christian Knowledge.

Cook, James \& James King. 1784. A Voyage to the Pacific Ocean, Undertaken, by the Command of His Majesty, for Making Discoveries in the Northern Hemisphere, to 
Determine the Position and Extent of the West Side of North America; Its Distance from Asia; and the Practicability of a Northern Passage to Europe. Performed Under the Direction of Captains Cook, Clerke, and Gore, in His Majesty's Ships the Resolution and Discovery, in the Years 1776, 1777, 1778, 1779, and 1780. Volume 1. Dublin: Chamberlaine.

. 1793. A Voyage to the Pacific Ocean, Undertaken by command of His Majesty, for Making Discoveries in the Northern Hemisphere, Performed under the direction of Captains Cook, Clerke, and Gore, in the years 1776, 1777, 1778, 1779, and 1780: being a copious, comprehensive, and satisfactory abridgement of the Voyage. Printed for Champante and Whitrow, \& M. Watson. London.

Crowley, Terry. 2000. An Erromangan (Sye) dictionary (Pacific Linguistics 508). Canberra: Australian National University.

- 2006a. Nese: a diminishing speech variety of Northwest Malakula, Vanuatu (Pacific Linguistics 577). Edited by John Lynch. Canberra: Australian National University.

- 2006b. Tape: a declining language of Malakula (Vanuatu) (Pacific Linguistics 575). Edited by John Lynch. Canberra: Pacific Linguistics.

Dixon, R.M.W. 1990. The origin of "Mother-in-Law vocabulary" in two Australian languages. Anthropological Linguistics 32 (1/2). 1-56.

Duhamel, Marie-France. 2021. The concept of taboo in Raga, Vanuatu: Semantic mapping and etymology. Oceania 91(1). 26-46.

Dumézil, Georges. 1958. L'idéologie tripartite des Indo-Européens. (Latomus XXXI.) Bruxelles: Latomus. $122 \mathrm{pp}$.

— 1995 [1968-1986]. Mythe et épopée (Bibliothèque Des Sciences Humaines). 3 volumes. Paris: Gallimard.

Durand, Marie. 2014. The materiality of the kitchen house: building, food and history on Mere Lava, northern Vanuatu. Doctoral thesis, University of East Anglia. https://ueaeprints.uea.ac.uk/48816/.

Ellis, William. 1831. Polynesian Researches, during a Residence of nearly Eight Years in the Society and Sandwich Islands. $2^{\text {nd }}$ ed., vol. 4. London: Fisher, Son \& Jackson.

Evans, Bethwyn. 2003. A study of valency-changing devices in Proto Oceanic (Pacific Linguistics 539). Canberra: Australian National University.

Evans, Nicholas. 2010. Semantic typology. In Jae Jun Song (ed.), The Oxford Handbook of Linguistic Typology. Oxford: Oxford University Press. 504-533.

Evans, Nicholas \& David Wilkins. 2000. In the mind's ear: The semantic extensions of perception verbs in Australian languages. Language 76(3). 546-592.

Fletcher, Adele. 2007. Sanctity, Power, and the "Impure Sacred": Analyzing Maori concepts of Tapu and Noa in early documentary sources. History of Religions 47(1). 51-74.

François, Alexandre. 2002. Araki. A disappearing language of Vanuatu. Pacific Linguistics, 522. Canberra: Australian National University.

- 2005a. Unraveling the history of the vowels of seventeen northern Vanuatu languages. Oceanic Linguistics 44 (2): 443-504. Dec 2005.

2005b. A typological overview of Mwotlap. Linguistic Typology 9-1: 115-146. 2008. Semantic maps and the typology of colexification: Intertwining polysemous networks across languages. In Martine Vanhove (ed.), From Polysemy to semantic change: Towards a typology of lexical semantic associations (Studies in Language Companion Series, 106), 163-215. Amsterdam: Benjamins. 
2009. The languages of Vanikoro: Three lexicons and one grammar. In Bethwyn Evans (ed.), Discovering history through language: Papers in honour of Malcolm Ross, 103-26. Canberra: Pacific Linguistics.

. 2011. Social ecology and language history in the Northern Vanuatu linkage: A tale of divergence and convergence. Journal of Historical Linguistics 1(2): 175246.

. 2013. Shadows of bygone lives: The histories of spiritual words in northern Vanuatu. In Robert Mailhammer (ed.). Lexical and structural etymology: Beyond word histories. Studies in Language Change, 11. Berlin: DeGruyter Mouton. 185-244.

. 2016. The historical morphology of personal pronouns in northern Vanuatu. In Konstantin Pozdniakov (ed.), Comparatisme et reconstruction: Tendances actuelles. Faits de Langues. Bern: Peter Lang. 25-60.

- 2017. The economy of word classes in Hiw, Vanuatu: Grammatically flexible, lexically rigid. Studies in Language 41 (2): 294-357.

. 2020. A cultural Mwotlap-English-French dictionary. Online version. Paris: CNRS. [https://tiny.cc/Mwotlap-dict]

- 2021a. Fonds Alexandre François: Archive of fieldwork recordings made in Vanuatu and the Solomon Islands. CoCoON (COllections de COrpus Oraux Numériques). Lattice-CNRS. [https://tiny.cc/Francois-archives]

. 2021b. An online Teanu-English dictionary. Lattice-CNRS. [https://tiny.cc/Teanu-dict, accessed 26 May 2021]

f/c. Lexical tectonics: Mapping structural change in patterns of lexification. In Thanasis Georgakopoulos \& Stéphane Polis (eds), The future of mapping: New avenues for semantic maps research. Special issue of Zeitschrift für Sprachwissenschaft.

François, Alexandre \& Monika Stern. 2013. Music of Vanuatu: Celebrations and Mysteries. Ebook released with the CD album Music of Vanuatu: Celebrations and Mysteries. Label Inédit. Paris: Maison des Cultures du Monde. 128 pp.

François, Alexandre, Michael Franjieh; Sébastien Lacrampe \& Stefan Schnell. 2015. The exceptional linguistic density of Vanuatu. In The Languages of Vanuatu: Unity and Diversity, ed. by A. François, S. Lacrampe, M. Franjieh \& S. Schnell. (Studies in the Languages of Island Melanesia, 5.) Canberra: Asia-Pacific Linguistics Open Access. 1-21.

François, Jacques. 2007. Pour une cartographie de la polysémie verbale. Collection Linguistique de la Société de Linguistique de Paris, 92. Paris, Louvain: Peeters.

- 2013. Semantische Karten für die vergleichende lexikologische Analyse europäischer Sprachen. Journal for EurolinguistiX 10 (2013): 15-28.

Georgakopoulos, Thanasis. 2019. Semantic maps. Linguistics. Oxford: Oxford University Press.

Georgakopoulos, Thanasis \& Stéphane Polis (eds). f/c. The future of mapping: New avenues for semantic maps research. Special issue of Zeitschrift für Sprachwissenschaft.

Georgakopoulos, Thanasis, Daniel A. Werning, Jörg Hartlieb, Tomoki Kitazumi, Lidewij van de Peut, Annette Sundermeyer, \& Gaëlle Chantrain. 2016. The meaning of ancient words for "Earth": An exercise in visualizing colexification on a semantic map. In Gerd Graßhoff \& Michael Meyer (eds), Space and Knowledge. Special issue of E-topoi, Journal for Ancient Studies 6: 418-452.

Gilmore, Helen, Cyril Schafer \& Siân Halcrow. 2013. "Tapu" and the invention of the "death taboo": An analysis of the transformation of a Polynesian cultural concept. Journal of Social Archaeology 13(3). 331-349. 
Gray, Andrew \& Pascal Temwakon. 2012. Bongmehee - Vehuran nii li daleda - Ol toktok lanwis blong Sentrol Pentikos - A dictionary of Apma language. Self publication. Port-Vila.

Guérin, Valérie. 2009. Mavea-English-Bislama dictionary. The Alice Cozzi Heritage Language Foundation. [https://sites.google.com/site/valerieguerin/publications]

Guy, Jacques. 1977. On the origins of the Sakao vowel system (New Hebrides). Journal of the Polynesian Society 86, 97-103.

Hammarström, Harald \& Robert Forkel \& Martin Haspelmath \& Sebastian Bank. 2021. Glottolog 4.4. Leipzig: Max Planck Institute for Evolutionary Anthropology. [https://glottolog.org, accessed on 12 June 2021]

Haspelmath, Martin. 2003. The geometry of grammatical meaning: Semantic maps and cross-linguistic comparison. In Michael Tomasello (ed.), The new psychology of language. New York: Erlbaum. 211-243.

Ivens, Walter G. 1931. The place of Vui and Tamate in the religion of Mota. Royal Anthropological Institute of Great Britain and Ireland 61.157-166.

Herbert, Robert K. 1990. Hlonipha and the Ambiguous Woman. Anthropos 85(4/6). 455-473.

Keesing, Roger. 1984. Rethinking mana. Journal of Anthropological Research 40.137156

. 1985. Conventional metaphors and anthropological metaphysics: The problematic of cultural translation. Journal of Anthropological Research 41(2). 201217.

. 1992. Some problems in the study of Oceanic religion. Anthropologica 34(2): 231-246.

Lynch, John. 1977. Lenakel dictionary (Pacific Linguistics). Canberra: Australian National University.

- 2001. The Linguistic History of Southern Vanuatu. (Pacific Linguistics) Canberra: Australian National University.

Lynch, John \& Philip Tepahae. 2001. Anejom̃ dictionary - Diksonari blong Anejoñ Nitasviitai a nijitas antas Anejor̃ (Pacific Linguistics 510). Canberra: Australian National University.

Malau, Catriona. 2016. A Grammar of Vurës, Vanuatu (Pacific Linguistics 651). Berlin: de Gruyter Mouton.

. f/c. A dictionary of Vurës, Vanuatu. Asia-Pacific Linguistics. Canberra: ANU Press.

Marett, Robert Ranulph. 1914. Is taboo a negative magic? in The Threshold of Religion. London: Methuen.

Meillet, Antoine. 1903. Introduction à l'étude comparative des langues indo-européennes. Paris: Librairie Hachette.

Mondragón, Carlos. 2004. Of Winds, Worms and Mana: The traditional calendar of the Torres Islands, Vanuatu. Oceania 74(4). 289-308.

- 2013. The meanings of mana in North Vanuatu: Cosmological dualism, Christianity and shifting forms of efficacious potency in the Torres Islands. Paper presented at international workshop New Mana: Transformations of a classic concept in Pacific languages and cultures. ANU, Canberra, Australia.

- 2015. Concealment, revelation and cosmological dualism. Visibility, materiality and the spiritscape of the Torres Islands, Vanuatu. Cahiers d'anthropologie sociale 11: 1. 38-50.

Pawley, Andrew. 2005. The meaning(s) of Proto Oceanic *panua. In Claudia Gross, Harriet D. Lyons \& Dorothy A. Counts (eds.), A Polymath Anthropologist: Essays 
In Honour of Ann Chowning (Research in Anthropology and Linguistics, Monograph 6), 211-223. University of Auckland: Department of Anthropology.

Pawley, Andrew K. \& Malcolm D. Ross. 1995. The prehistory of Oceanic languages: A current view. In Peter S. Bellwood, James J. Fox \& Darrell Tryon (eds.), The Austronesians: Historical and Comparative Perspectives, 39-80. Canberra: Australian National University.

Pizarro Pedraza, Andrea (ed.) 2018. Linguistic Taboo Revisited: Novel Insights from Cognitive Perspectives. (Cognitive Linguistics Research, 61.) Berlin: DeGruyter Mouton.

Rankin, Robert. 2003. The Comparative Method. In Brian D. Joseph \& Richard D. Janda (eds.), The Handbook of Historical Linguistics, 183-212. Oxford: Blackwell.

Ross, Malcolm, Andrew Pawley \& Meredith Osmond. 1998-2016. The lexicon of Proto Oceanic (Pacific Linguistics). Five volumes. Canberra: Australian National University.

Sachdev, Perminder S. 1989. "Mana, Tapu, Noa": Maori cultural constructs with medical and psycho-social relevance. Psychological Medicine 19(4). 959-969.

Stasch, Rupert. 2011. Word avoidance as a relation-making act: A paradigm for analysis of name utterance taboos. Anthropological Quarterly 84(1). 101-120.

Steiner, Franz Baermann. 1999. Taboo, truth, and religion: Selected writings (Methodology and History in Anthropology v. 2-3). Edited by J. D. Adler \& R. Fardon. New York: Berghahn Books.

Sweetser, Eve E. 1990. From etymology to pragmatics: Metaphorical and cultural aspects of semantic structure. (Cambridge Studies in Linguistics, 54.) Cambridge: Cambridge Univ. Press.

Taylor, John Patrick. 2008. The other side: ways of being and place in Vanuatu (Pacific Islands Monograph Series 22). Honolulu: University of Hawai'i Press.

Thieberger, Nick. 2011. A South Efate dictionary. Parkville, Vic.: University of Melbourne. [http://hdl.handle.net/11343/28968, accessed 12 May 2021]

Touati, Benjamin. 2015. The initial vowel copy in the Sakao dialect of Wanohe (Espiritu Santo). In The Languages of Vanuatu: Unity and Diversity, ed. by A. François, S. Lacrampe, M. Franjieh \& S. Schnell. Studies in the Languages of Island Melanesia, 5. Canberra: Asia Pacific Linguistics Open Access. 77-90.

Treis, Yvonne. 2005. Avoiding their names, avoiding their eyes: How Kambaata women respect their in-laws. Anthropological Linguistics 47(3). 292-320.

von Prince, Kilu. 2017. Daakaka dictionary. Dictionaria 1. 1-2167. [https://dictionaria.clld.org/contributions/daakaka, accessed 27 May 2021]

Vernier, Charles. 1948. Les variations du vocabulaire tahitien avant et après les contacts européens. Journal de la Société des Océanistes 4.4: 57-85.

Vienne, Bernard. 1984. Gens de Motlav. Idéologie et pratique sociale en Mélanésie. (Société des Océanistes, 42.) Paris: Société des Océanistes.

- 1996. Masked faces from the country of the Dead. In Joël Bonnemaison, Kirk Huffman, Christian Kaufmann \& Darrell Tryon (eds.), Arts of Vanuatu, 234-246. Bathurst: Crawford House Press.

Williams, Herbert W. 1957 [1917]. A Dictionary of the Maori Language. Sixth edition. New Zealand Texts Collection. Wellington: Government Printer.

Williamson, Robert W. 1937. Religion and social organization in central Polynesia. Cambridge: Cambridge University Press.

Yoshioka, Masanori. 1994. Taboos and tabooed: Women in North Raga of Vanuatu. In Katsuhiko Yamaji (ed.), Gender and Fertility in Melanesia, 75-108. Dept. of Anthropology, Kwansei Gakuin University. 